\title{
高炉スラグのコンクリートへの利用に関する研究 \\ STUDY ON THE USE OF BLASTFURNACE SLAG IN CONCRETE
}

\section{1. 緒 論}

高炬スラグがコンクリート用材料として利用されたの は新しいことではなく, 約 70 年以前からスラグセメン トの原料としてわが国でも使用されている. 近年，わが 国製鉄業の急速な発展により銑鉄生産に伴って発生する 高炉スラグは膨大な量に達しているので, その利用につ いては, 従来よりもいっそう広汎な研究が開始されてい る.これは，わが国の資源ならびにエネルギーの節約， 自然環境保全の要請に応えることにもなるので, 高炉ス ラグの適切な利用法の研究は, いまや国家的な緊急課題 となっている.

高炉スラグをコンクリート用材料として使用するにあ たって, 3 種の方法が考えられる. 第 1 の方法として は，徐冷却してできた高炉スラグ粗骨材をコンクリート 用粗骨材として用いることがあげられるが，この方法に ついては, すでに多くの研究が実施され, 公表されてい る調查研究結果も多く1) 5)，製鉄所の建設にこれを利用 した実績も少なくない.しかし高炉スラグ粗骨材は, 冷 却処理の方法, その他によってその品質が著しく異なる ものである. そこで品質が相違する高炉スラグ粗骨材を コンクリートに用いた場合コンクリートの性質に及ぼす 影響について解明する必要がある. 第 2 の方法は, 急冷 して破砕処理した高炉スラグ砕砂, 高炉スラグ空砕砂を 細骨材として用いることである. 高炉スラグ砕砂の使用 実績は，製鉄所構内の建設工事にわずか使用されている だけで, 高炉スラグ空砕砂の使用実績については，ほと んどないのが現状である. しかし最近特にこれらについ ての研究が活発に行われ始めた ${ }^{6) ~ 8)}$.これは, 高炉スラ グ砕砂, 高炉スラグ空砕砂のもつ潜在水硬性をも活用し ようとする意図に基づくものである. 高炉スラグ細骨材 は, 溶融高炉スラグを水または空気を用いて急冷処理し

\footnotetext{
* 正会員 工修 武蔵工業大学助教授 工学部土木工学科
}

小 玉 克 巳*

By Katsumi KODAMA
たものをロッドミル，ハンマーミル等で適当に破砕し， 粒形を整えるとともに粒度を調整したものであるので, これらの品質が泠却および破砕の方法によって相当に異 なる. 高炉スラグ砕砂の場合には, 粗粒のものの強さが 川砂の粗粒のものに比べて弱く, 粒形も角ばっているこ とである．高炉スラグ空砕砂の場合には，粗粒のものは 丸味を呈しており, 粒自身の強さも川砂粒と大差なく, ち密であるが，ほとんどが粒径 $0.6 \mathrm{~mm}$ 以上であり， $0.6 \mathrm{~mm}$ 以下は粗粒のものを破砕して粒度調整を行って いるため細粒のものは, 粒形が角ばっている.また高炉 スラグ細骨材は, 破砕して 粒度調整するため $0.15 \mathrm{~mm}$ 以下の微粒分が多く含まれることもある.これら高炉ス ラグ細骨材をコンクリートに使用した場合のコンクリー トの性質に及ぼす影響についての検討が必要である．第 3 の方法は, 急泠して得られる軟質高炉スラグを適当に 粉砕処理した高炉スラグ微粉末をコンクリート用混和材 として用いることが考えられる．高炉セメントの原料と しての高炉スラグは，すでに古くから実用されている. その使用方法については, ほぼ定説も得られているが9， コンクリート用混和材として用いられた例はない. 現在 市販されている高炉セメントを用いる場合には, 高炉ス ラグの品質, 混入量等は限定されることになる. 混和材 として用いる場合には最も適当と思われる品質の高炉ス ラグを任意の割合で混入することが可能となる．高炉ス ラグ微粉末を混和材としてコンクリートに用いた場合の 高炉スラグの品質, 混入量等がコンクリートの性質に及 ぼす影響についても解明することが重要なことである.

本論文は, 高炉スラグをコンクリート用材料として用 いる場合の基礎的諸事項に関し, 武蔵工業大学コンクリ ート研究室で実施した研究結果を取りまとめたものであ って, 代表的な高炉スラグ粗骨材, 高炉スラグ砕砂, 空 砕砂ならびに高炉スラグ微粉末の特性についての実験結 果に基ゔき，これらを使用したコンクリートの諸性質に ついて論じたものである. 実験の一部には, 建材試験セ 
ンターコンクリート用高炉スラグ骨材標準化研究委員会 の大規模な調查研究の一環として筆者が実施した研究結 果も含まれているのである.

\section{2. 高炬スラグ粗骨材が コンクリートのコンシ ステンシー，強度に及ぼす影響}

\section{(1) 使用材料}

本実験に用いた粗骨材は，製鉄所の異なる A, B, C の 3 種類の高炉スラグ と比較のための川砂利である. 表一1 は実験に用いた 3 種の高炉スラグ粗骨材と川砂利 の試験結果である．細骨材は，いずれも同じ川砂を用 い, 試験結果は 表一2 のごとくである.

表一1 より単位容積重量は, 実験に使用した高炉スラ グ粗骨材すべてが土木学会コンクリート標準示方書限度 $1250 \mathrm{~kg} / \mathrm{m}^{3}$ より大きい值となっている. 実績率は 57〜 60\% で川砂利の実績率より小さい值を示しているが， いずれも JISA 5005「コンクリート用研石」の規格值 55\% を超えており，表一8 の砕石 (1)，(2) の実績率の 值と大体一致している. すりへり減量值は 41 47\% で

\section{表一1 粗骨材の物理的性質}

\begin{tabular}{|c|c|c|c|c|c|c|}
\hline \multirow{2}{*}{ 試験項目 } & & \multicolumn{3}{|c|}{ 高炉スラグ粗骨材 } & \multirow{2}{*}{ 川砂利 } & \multirow{2}{*}{$\begin{array}{l}\text { 普 通 } \\
\text { 碎 }\end{array}$} \\
\hline & & A & B & $\mathrm{C}$ & & \\
\hline 表 乾 比 & 重 & 2.54 & 2.31 & 2.56 & 2.66 & 2.60 \\
\hline 吸 水 率 & $(\%)$ & 3.34 & 5.47 & 2.74 & 1.11 & 0.96 \\
\hline \multicolumn{2}{|c|}{ 単位容積重量 $\left(\mathrm{kg} / \mathrm{m}^{3}\right)$} & 1423 & 1306 & 1385 & 1777 & 1530 \\
\hline 実 積 率 & $(\%)$ & 57.8 & 59.7 & 55.5 & 67.0 & 59.4 \\
\hline 洗 い試 験 & $(\%)$ & 1.20 & 1.41 & 1.11 & 0.93 & 0.36 \\
\hline すりへり減量 & $(\%)$ & 41.3 & 46.9 & 43.5 & 13.1 & 13.8 \\
\hline $\begin{array}{l}\text { BS 規格によ吾 } \\
\text { 破砕試験 }\end{array}$ & $(\%)$ & 29.6 & 31.9 & 31.1 & 10.5 & 13.7 \\
\hline & 20 & 10.0 & 14.5 & 14.8 & 14.7 & 14.7 \\
\hline 觉金 & 15 & 23.3 & 28.5 & 42.2 & 31.0 & 31.0 \\
\hline 量百分率 & 10 & 69.8 & 64.5 & 78.2 & 80.0 & 80.0 \\
\hline$(\mathrm{mm})$ & 5 & 98.4 & 95.6 & 98.0 & 100.0 & 100.0 \\
\hline 粗 & 率 & 6.77 & 6.74 & 6.91 & 6.95 & 6.95 \\
\hline
\end{tabular}

\section{表一2 細骨材の物理的性質}

\begin{tabular}{|c|c|c|c|c|c|c|c|c|c|}
\hline \multirow{2}{*}{$\begin{array}{l}\text { 表㲦 } \\
\text { 比重 }\end{array}$} & \multirow{2}{*}{$\begin{array}{c}\text { 吸水率 } \\
(\%)\end{array}$} & \multirow{2}{*}{ 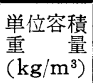 } & \multirow{2}{*}{$\begin{array}{l}\text { 洗 W } \\
\text { 試 } \\
(\%)\end{array}$} & \multicolumn{5}{|c|}{ 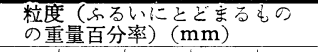 } & \multirow{2}{*}{ 粗粒率 } \\
\hline & & & & 2.5 & 1.2 & 0.6 & 0.3 & 0.15 & \\
\hline 2.58 & 3.0 & 1725 & 2.56 & 16.5 & 30.7 & 58.6 & 79.8 & 97.6 & 2.83 \\
\hline
\end{tabular}

あり，英国規格による破砕試験值は，30３2\% であっ て川砂利の試験值に比較して両者とも 3 倍の值となって いる.また粒形の角ばりの影響も考えられるので普通砕 石と比較した結果，両試験值とも約 3 倍の值となってい る.これらは，高炉スラグ粗骨材粒が多孔質であるばか りでなく，その材質も一般骨材粒より相当に強さが弱い ことを示すものである.

3 種の高炉スラグ粗骨材の使用にあたっては，あらか じめふるい分けたものを所定の粒度に調整して用いた。 なお, 高炉スラグ粗骨材は, ある程度まで吸水した気乾 状態で貯蔵したものを使用前に 24 時間吸水させたのち 粒の表面を布でぬぐい表面乾燥飽水状態として使用し た. 川砂利は， 24 時間吸水させ表面乾燥飽水状態で用 いた. 細骨材は, 表面水率を $1 \%$ 以内にした状態で貯蔵 し,これの表面水を測定して用いた. セメントは, 日本 セメント（株）製の普通ポルトランドセメントでその試 験成績は表一3のごとくである.

\section{（2）高虾スラグ粗骨材を用いたコンクリートのコン システンシー}

一定の粒度とした 3 種の高炉スラグ粗骨材と川砂利と を用いた場合について，コンクリートの水セメント比お よび単位水量を一定に保ちながら細骨材率を変化させ, VB 試験を実施してコンシステンシーの比較検討をし た. 水セメント比を $40,50,60 \%$ の 3 種類, 単位水量 を $150,160,170 \mathrm{~kg}$ の 3 種類とした組合せで実験した のである.

各細骨材率のコンクリートに対する VB 值を求めた 結果の 1 例は，図一1 のごとくである．図一1 より高炉

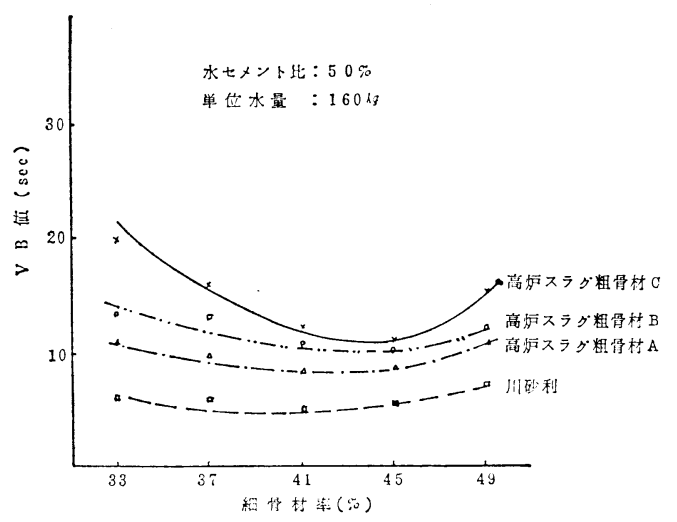

図-1 コンクリートの細骨材率と VB 值との関係

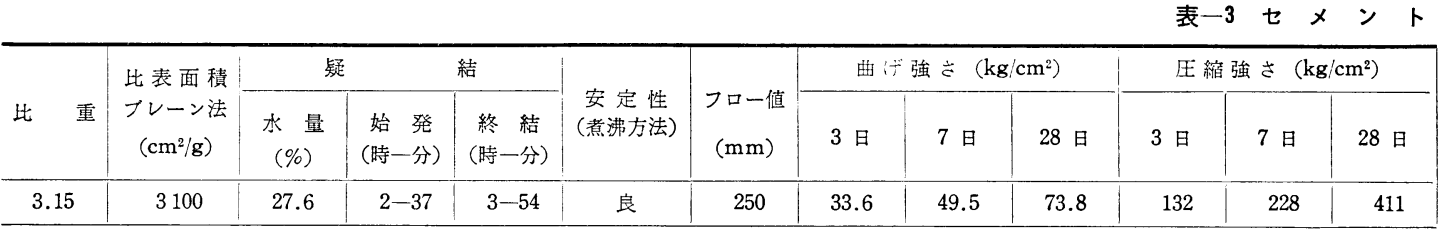


表一4 コンクリートの最適細骨材率と VB 值 (カッコ内)

\begin{tabular}{|c|c|c|c|c|c|}
\hline \multirow{3}{*}{$\begin{array}{c}\text { 水セX } \\
\text { ント比 } \\
(\%)\end{array}$} & \multirow{3}{*}{$\begin{array}{c}\text { 単位水量 } \\
(\mathrm{kg})\end{array}$} & \multicolumn{4}{|c|}{ 最適細骨材率 (\%) と VB 值 (SEC) } \\
\hline & & \multicolumn{3}{|c|}{ 高炈スラク粗骨材コンクリート } & \multirow{2}{*}{$\begin{array}{l}\text { 川砂利コン } \\
\text { クリート }\end{array}$} \\
\hline & & A & B & $\mathrm{C}$ & \\
\hline \multirow{4}{*}{40} & 140 & - & - & - & 37 (12) \\
\hline & 150 & $42(14)$ & $43(16)$ & 44 (17) & $39(8)$ \\
\hline & 160 & $41(8)$ & $41(10)$ & 42 (12) & 39 (5) \\
\hline & 170 & $41(6)$ & $41(6)$ & $42(8)$ & - \\
\hline \multirow{4}{*}{50} & 140 & - & - & - & $41(9)$ \\
\hline & 150 & 42 (11) & $43(13)$ & 44 (15) & $40(7)$ \\
\hline & 160 & $43(8)$ & $44(10)$ & 44 (11) & $40(5)$ \\
\hline & 170 & $43(6)$ & $44(7)$ & 45 ( 9$)$ & - \\
\hline \multirow{4}{*}{60} & 140 & - & - & - & $41(8)$ \\
\hline & 150 & $43(9)$ & 44 ( 8 ) & 45 (13) & $41(5)$ \\
\hline & 160 & $43(6)$ & $44(6)$ & $44(9)$ & $41(4)$ \\
\hline & 170 & $44(6)$ & $45(6)$ & $45(8)$ & - \\
\hline
\end{tabular}

スラグ粗骨材を用いたコンクリートについても, VB 值 が最小となる細骨材率の存在することが示されている. 水セメント比, 単位水量を一定とした場合において, VB 值が最小となる細骨材率を最適細骨材率と考え, そ の值を示せば，表一4 のようになる．表一4によれば， 高炉スラグ粗骨材コンクリートにおける最適細骨材率 は, 川砂利コンクリートより $2 \sim 4 \%$ 程度大きくなって いる.

次に，3 種の高炉スラグ粗骨材がコンクリートのコン システンシーに及ぼす影響を検討した．それぞれの粗骨 材に対し, ある水セメント比をもつコンクリートの場 合, 最適細骨材率における単位水量と VB 值との関係 の 1 例を図示すると図一2 のごとくである.また 図一2

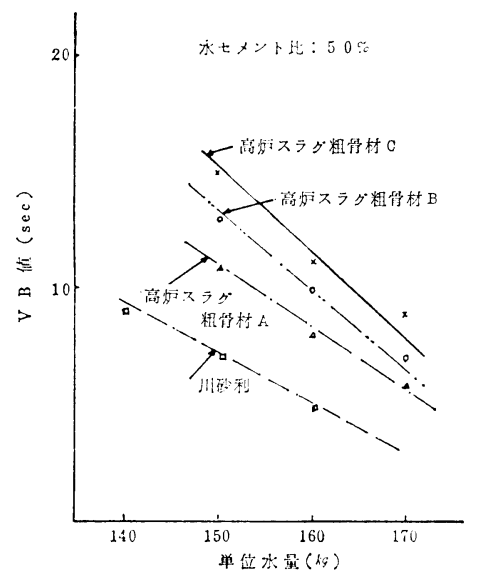

図一2 最適細骨材率における単位水量と VB 值との関係
表一5VB 值が 8 sec のときのコンクリートの単位水岳

\begin{tabular}{|c|c|c|c|c|c|}
\hline \multirow{2}{*}{$\begin{array}{c}\text { 水セメント比 } \\
(\%)\end{array}$} & \multirow{2}{*}{$\begin{array}{l}\text { VB 值 } \\
\text { (SEC) }\end{array}$} & \multicolumn{3}{|c|}{ 高炬スラク粗骨材コンクリート } & \multirow{2}{*}{$\begin{array}{l}\text { 川砂利コン } \\
\text { クリート }\end{array}$} \\
\hline & & $A(k g)$ & $\mathrm{B}(\mathrm{kg})$ & $\mathrm{C}(\mathrm{kg})$ & \\
\hline 40 & 8 & 160 & 163 & 170 & 150 \\
\hline 50 & 8 & 160 & 166 & 170 & 146 \\
\hline 60 & 8 & 157 & 160 & 170 & 143 \\
\hline
\end{tabular}

よりVB 值が 8 秒となるコンクリートの単位水量を比 較すれば, 表一5 のごとくになる.表一5 より, 水セメ ント比 $50 \%$ の場合高炉スラグ粗骨材コンクリートで川 砂利コンクリートと同程度のコンシステンシーを得るた めには，単位水量を高炬スラグ粗骨材 A で約 $15 \mathrm{~kg}, \mathrm{~B}$ で約 $20 \mathrm{~kg}$ ，Cで約 $24 \mathrm{~kg}$ 増加しなければならない。こ れは高炉スラグ粗骨材の粒形が角ばっており, 表面も粗 であることによるものである.

\section{（3）高炉スラグ粗骨材がコンクリートの強度に及ぼ す影響}

粗骨材の最大寸法を $25 \mathrm{~mm}$ ，水セメント比を $50 \%$, $60 \%$ の 2 種，それぞれスランプを $8 \mathrm{~cm}$ としたコンク リートについて, A, B および C の 3 種類の高炉スラグ 粗骨材がコンクリートの強度に及ぼす影響を試験した. これらの粗骨材を用いた場合と川砂利を用いた場合とを 比較検討した. コンクリートの圧縮供試体は, 直径 10 $\mathrm{cm}$, 高さ $20 \mathrm{~cm}$ の円柱形, 曲げ供試体は, $15 \times 15 \times 53$ $\mathrm{cm}$ の角柱形, 引張供試体は, 直径 $15 \mathrm{~cm}$, 高さ $15 \mathrm{~cm}$ の円柱形であって，それぞれ JIS に準拠して試験を行 った.

a) 圧縮強度

図一3 は, $21^{\circ} \mathrm{C}$ 水中で養生した場合の各種粗骨材コ ンクリートにおける材令と圧縮強度との関倸の 1 例を示 したもので, 表一6 は川砂利コンクリートに対する強度 比を示したものである. 表一6より, 高炉スラグ粗骨材 コンクリートの圧縮強度は, 水セメント比およびュンシ ステンシーを同じにした川砂利コンクリートの圧縮強度 より材令 7 日〜56 日のいずれの材令においても大きく なるが，大きくなる程度は水セメント比によって相違す ることが認められる.すなわち圧縮強度比は, 水セメン 卜比 60\% の場合, 高炉スラグ粗骨材 Aで 150 131\%, B および C で 127 111\% であったが, 水セメント比 $50 \%$ とした場合には，3種類の高炉スラグ粗骨材にお ける差は僅少となり, いずれも 130 110\% であり, い

\section{の試 験 成 績}

\begin{tabular}{|c|c|c|c|c|c|c|c|c|c|c|c|c|c|}
\hline & & 化 & 学 & 成 & 分 & $(\%)$ & & & \multirow{2}{*}{ 水硬率 } & \multicolumn{2}{|r|}{ : } & \multicolumn{2}{|c|}{ 数 } \\
\hline 熱強減量 & 不溶残分 & 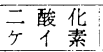 & $\begin{array}{c}\text { 酸化アル } \\
\text { ミ }\end{array}$ & $\begin{array}{l}\text { 酸 } \\
\text { 第二鉄 }\end{array}$ & $\begin{array}{l}\text { 酸化力 } \\
\text { ルシウム }\end{array}$ & $\begin{array}{l}\text { 酸化マク } \\
\text { 木ンウム }\end{array}$ & 百酸华 & 合 計 & & 话動係数 & けい酸率 & 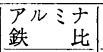 & $\begin{array}{l}\text { 石 扊 } \\
\text { 飽和度 }\end{array}$ \\
\hline ig. loss & in. sol & $\mathrm{SiO}_{2}$ & $\mathrm{Al}_{2} \mathrm{O}_{3}$ & $\mathrm{Fe}_{2} \mathrm{O}_{3}$ & $\mathrm{CaO}$ & $\mathrm{MgO}$ & $\mathrm{SO}_{3}$ & Total & H.M. & A.I. & S.M. & I.M. & LS.D. \\
\hline 0.4 & 0.1 & 22.3 & 5.2 & 3.0 & 65.0 & 1.2 & 2.2 & 99.4 & 2.08 & 4.3 & 2.7 & $\begin{array}{ll}1.7 \\
\end{array}$ & 0.90 \\
\hline
\end{tabular}


表一6 川砂利コンクリートに対する強度比

\begin{tabular}{|c|c|c|c|c|c|c|c|c|c|c|c|c|c|c|c|c|c|c|c|c|}
\hline \multirow{3}{*}{$\begin{array}{c}\text { 水セメント比 } \\
(\%)\end{array}$} & \multirow{3}{*}{\multicolumn{2}{|c|}{$\begin{array}{l}\text { 粗骨材の } \\
\text { 種 類 }\end{array}$}} & \multicolumn{18}{|c|}{ 各材令における川砂利コンクリートに対する強度比（\%) } \\
\hline & & & \multicolumn{4}{|c|}{ 圧 } & \multicolumn{2}{|c|}{ 縮 } & \multicolumn{4}{|c|}{ 曲 } & \multicolumn{2}{|c|}{ げ } & \multicolumn{4}{|c|}{ 引 } & \multicolumn{2}{|l|}{ 張 } \\
\hline & & & \multicolumn{2}{|c|}{7 日 } & \multicolumn{2}{|c|}{28 日 } & \multicolumn{2}{|c|}{56 日 } & \multicolumn{2}{|c|}{7 日 } & \multicolumn{2}{|c|}{28 日 } & \multicolumn{2}{|c|}{56 日 } & \multicolumn{2}{|c|}{7 日 } & \multicolumn{2}{|c|}{28 日 } & \multicolumn{2}{|c|}{56 日 } \\
\hline & 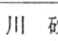 & 利 & \multicolumn{2}{|c|}{100} & \multicolumn{2}{|c|}{100} & \multicolumn{2}{|c|}{100} & \multicolumn{2}{|c|}{100} & \multicolumn{2}{|c|}{100} & \multicolumn{2}{|c|}{100} & \multicolumn{2}{|c|}{100} & \multicolumn{2}{|c|}{100} & \multicolumn{2}{|c|}{100} \\
\hline \multirow[t]{3}{*}{50} & \multirow{3}{*}{ 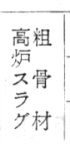 } & A & 122 & \multirow{3}{*}{$\begin{array}{l}\text { 平均 } \\
126\end{array}$} & 126 & \multirow{3}{*}{$\begin{array}{r}\text { 平均 } \\
130\end{array}$} & 109 & \multirow{3}{*}{$\begin{array}{c}\text { 平均 } \\
110\end{array}$} & 97 & \multirow{3}{*}{$\begin{array}{r}\text { 平均 } \\
105\end{array}$} & 108 & & 116 & & 87 & & 89 & & 101 & 平均 \\
\hline & & B & 122 & & 131 & & 110 & & 103 & & 101 & $\begin{array}{r}\text { 平均 } \\
110\end{array}$ & 109 & 115 & 113 & 104 & 93 & 91 & 103 & 103 \\
\hline & & $\mathrm{C}$ & 133 & & 133 & & 111 & & 114 & & 120 & & 120 & & 112 & & 92 & & 103 & \\
\hline & 川 石 & 利 & & 00 & & 00 & & 00 & & 00 & & 0 & & 00 & & 00 & 1 & 00 & 10 & 00 \\
\hline 60 & 高祖 & A & & 50 & & 31 & & 34 & & 27 & & 20 & & 28 & & 43 & 1 & 14 & & 15 \\
\hline & 棺骨 & B & 126 & 平均 & 112 & 平均 & 112 & 平均 & 123 & 平均 & 101 & 平均 & 110 & 平均 & 131 & 平均 & 114 & 平均 & 106 & 平均 \\
\hline & $\begin{array}{l}\text { 亏 } \\
\text { 材 }\end{array}$ & $\mathrm{C}$ & 127 & 127 & 111 & 112 & 115 & 114 & 128 & 126 & 120 & 111 & 118 & 114 & 125 & 128 & 113 & 114 & 110 & 108 \\
\hline
\end{tabular}

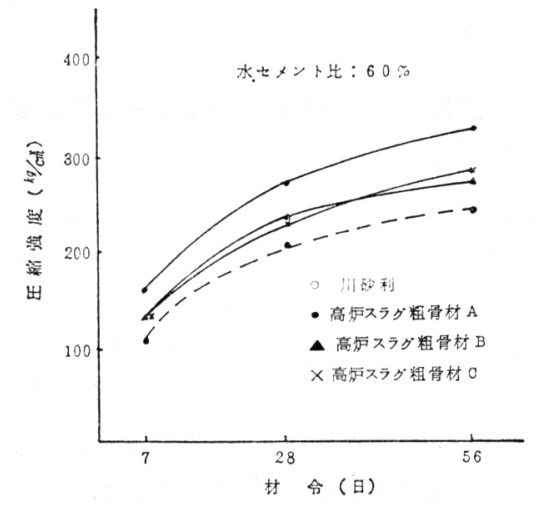

図一3 コンクリートの材令と圧縮強度との関係

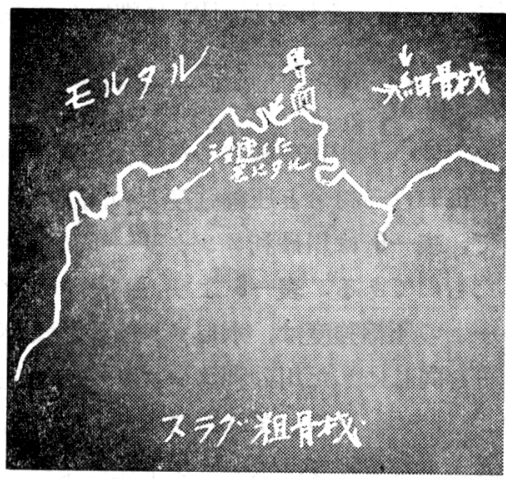

(W/C $65 \%$, 材令 56 日, スラク粗骨材 C の場合)

写真一1 スラグ粗骨材粒界面部の検鏡結果の 1 例 $(\times 160)$

ずれの高炬スラグ粗骨材コンクリートも川砂利コンクリ ートより強度が大きくなることが認められる.この理由 は, 高炉スラグ粗骨材の粒表面が粗であるため, 写真一 1 にみられるように, 粒表面の回部にモルタルが浸透 し, 高炉スラグ粗骨材界面との結合強度が増すことによ って強度が大きくなったと考えられる。

また水セメント比が小さくなることによる各高炉スラ グ粗骨材による差が僅少となったのは, 高炉スラグ粗骨 材粒の凹部にモルタルが浸透し, 高炉スラグ粗骨材粒の
弱さをモルタルの強度が補っているものと考えられる。

しかし材令が経過するほど川砂利コンクリートの強度 に近くなっている. 吉田 ${ }^{2)}$ の報告によると，材令 7 日の 圧縮強度試験では, 高炉スラグ粗骨材粒は破壊せず, そ のためセメントペーストと骨材の付着強度の大きい高炉 スラグ粗骨材コンクリートの強度が大きくなるが，材令 56 日では, セメントペーストの強度がセメントの水和 により大きくなり，高炉スラグ粗骨材自身が破壊するよ うになると述べており，本実験でも同様な結果が認めら れた. 表一1 に上机ば, 各高炉スラグ粗骨材のすりへり 減量值ならびに破砕圾験值は, 川砂利の試験值の約 3 倍 に達して抢り，3 種の高炉スラグ粗骨材粒の強さが川砂 利粒の強さに比べて相当汇劣ることが示されている.粗 骨材の絶対容積を同一に保って比較した実験ではなく， コンクリート中における高炉スラグ粗骨材の 絶対容積 は, 川砂利の絶対容積の約 $90 \%$ であるので㛜密な比較 とはいえないが，骨材粒の強さに扔いて劣る高炉スラグ 粗骨材を用いたコンクリートの方が圧縮強度が大きくな った理由は前述のごとくであると考えられる.

b）曲げ強度および引張強度

図一 - 5 には，各種粗骨材コンクリートにおける材 令と曲汸強度, 引張強度との関倸の 1 例を示してある.

表一6 亿よれば, 高炉スラグ粗骨材コンクリートの曲げ 強度は, 水セメント比を同じにした川砂利コンクリート の曲げ強度より材令 7 日〜 56 日のいずれにおいても大 きくなるが，大きくなる程度は，圧縮強度の場合と同様 に水セメント比によって相違することが認められる.す なわち, 曲げ強度比は, 水セメント比 $60 \%$ の場合に は，材令 56 日で高炉スラグ粗骨材 A で 128\%，B で 110\%，Cで 118\% であったが，水セメント比 50\% の 場合には，材令 56 日で高炉スラグ粗骨材 A で 116 \%, B で 109\%, C で 120\% となり, 水セメント比 50 \%の場合の方が曲治度比がわずかに小さくなり，3 種類の粗骨材による曲汭強度の差も小さくなっている. 


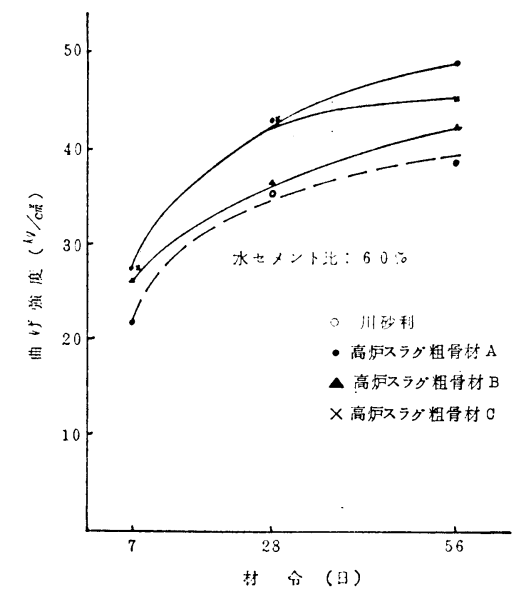

図-4 コンクリートの材令と曲げ強度との関係

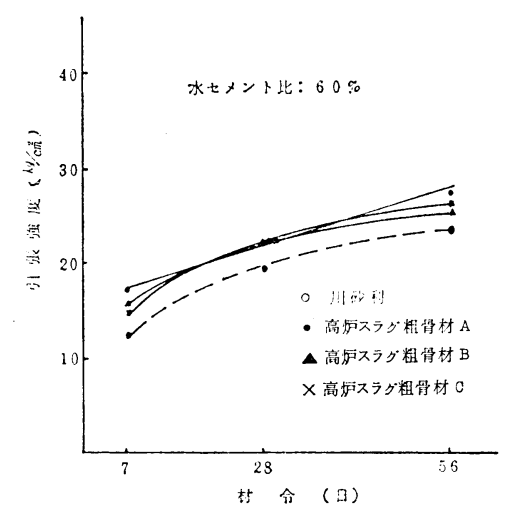

図一5 コンクリートの材令と引張強度との関係

曲げ試験後の供試体の破断面において, 高炉スラグ粗骨 材がほとんど破断されているのに高炉スラグ粗骨材を用 いたコンクリートの方が曲げ強度が大きくなった理由も 圧縮強度の場合と同様と考えられる。

表一6によれば, 引張強度は, 曲げ強度の場合と若干 異なっている. 水セメント比 $60 \%$ の場合には, 川砂利
コンクリートより，いずれの材令においても大きくなる が, 水セメント比 $50 \%$ の場合には, 川砂利コンクリー トの引張強度と同等かやや小さくなっている. また 3 種 の高炉スラグ粗骨材における強度差は, ほとんど認めら れず, 試験後の供試体破断面の高炉スラグ粗骨材粒がす べて破断されており，粒自身の弱いことの影響が，圧縮 強度, 曲げ強度の場合より著しくなったことによるもの である・

\section{3. 高炬スラグ細骨材が コンクリートのコンシ ステンシー，強度に及ぼす影響}

\section{(1) 使用材料}

高炉スラグ細骨材として，水で急冷した高炉スラグ砕 砂と空気で急冷した高炉スラグ空砕砂を用いた. 高炉ス ラグ細骨材は，ほとんどが破砕加工して細骨材とするた め $0.15 \mathrm{~mm}$ ふるい以下の微粒分の量が多くなることが 予想されるが，この微粒分を洗い去ることは環境を污染 する恐れがあるので不可能と思われる. また高炉スラグ 細骨材の潜在水硬性を活用するためには, 微粒分はある 程度まで多いことが望ましい.

それで高炉スラグ砕砂を用い, 各粒が $5 \sim 0.15 \mathrm{~mm}$ ふ るいの範囲内に適当に分布するとともに相当量の微粒分 をも含む $\mathrm{A}$ と粒の大部分が $1.2 \sim 0.15 \mathrm{~mm}$ ふるいの範 囲内に分布している B を用いたコンクリート，および 高炉スラグ空砕砂を用いたコンクリートについて試験 し,川砂を用いた場合と比較検討した.

実験に用いた細骨材, 粗骨材の物理的性質は, 表一7, 8 のごとくである. 高炉スラグ砕砂の吸水率は, 川砂の 場合と大差ないので, いずれも湿潤状態とし, 使用にあ たっては，その表面水率を測定してコンクリートの練り 混ぜ用水を補正した. 高炉スラグ空砕砂も同様とした.

表一7 細骨材の物 理的性質

\begin{tabular}{|c|c|c|c|c|c|c|c|c|c|c|c|c|}
\hline \multirow{2}{*}{$\begin{array}{l}\text { 細骨材の } \\
\text { 種 類 }\end{array}$} & \multirow{2}{*}{ 表乾比重 } & \multirow{2}{*}{$\begin{array}{c}\text { 吸 水 率 } \\
(\%)\end{array}$} & \multirow{2}{*}{$\begin{array}{l}\text { 単位容積 } \\
\text { 重 量 } \\
\left(\mathrm{kg} / \mathrm{m}^{3}\right)\end{array}$} & \multirow{2}{*}{$\begin{array}{c}\text { 実 績 率 } \\
(\%)\end{array}$} & \multicolumn{6}{|c|}{ 粒度（ふるいにとどまるものの重量百分率）(mm) } & \multirow{2}{*}{ 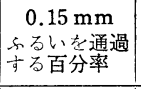 } & \multirow{2}{*}{ 粗 粒 率 } \\
\hline & & & & & 5.0 & 2.5 & 1.2 & 0.6 & 0.3 & 0.15 & & \\
\hline A & 2.67 & 3.07 & 1547 & 59.7 & 3 & 23 & 43 & 55 & 67 & 81 & 19 & 2.72 \\
\hline $\mathrm{B}$ & 2.67 & 2.00 & 1440 & 55.6 & 0 & 0 & 3 & 33 & 80 & 94 & 6 & 2.09 \\
\hline 川 矽 (1) & 2.59 & 2.52 & 1632 & 64.6 & 0 & 5 & 22 & 51 & 81 & 96 & 4 & 2.55 \\
\hline 确 & 2.90 & 0.54 & 1859 & 64.3 & 0 & 0.2 & 36.0 & 68.0 & 83.0 & 94.0 & 6.0 & 2.80 \\
\hline 川 砂 (2) & 2.59 & 3.70 & 1596 & 63.9 & 0 & 0.2 & 36.0 & 68.0 & 83.0 & 94.0 & 6.0 & 2.80 \\
\hline
\end{tabular}

表一8 粗骨材 の物理的性質

\begin{tabular}{|c|c|c|c|c|c|c|c|c|c|c|c|}
\hline \multirow{2}{*}{ 種 } & \multirow{2}{*}{\multicolumn{2}{|c|}{ 類 }} & \multirow{2}{*}{ 表乾比重 } & \multirow{2}{*}{$\begin{array}{c}\text { 吸 水率 } \\
(\%)\end{array}$} & \multirow{2}{*}{$\begin{array}{l}\text { 単位容積 } \\
\text { 重 量 } \\
\left(\mathrm{kg} / \mathrm{m}^{3}\right)\end{array}$} & \multirow{2}{*}{$\begin{array}{c}\text { 実 績率 } \\
(\%)\end{array}$} & \multicolumn{3}{|c|}{ 粒度 (残留重量百分率) (mm) } & \multirow{2}{*}{ 粗 粈率 } & \multirow{2}{*}{ 用いた試験内容 } \\
\hline & & & & & & & 15 & 10 & 5 & & \\
\hline 川 & 砂 & 利 & 2.67 & 1.11 & 1699 & 64.4 & 35 & 65 & 100 & 6.65 & コンンステンンー試験 \\
\hline 碎 & 石 & (1) & 2.61 & 1.10 & 1483 & 57.4 & 35 & 65 & 100 & 6.65 & コンクリート強度試験 \\
\hline 砕 & 石 & $(2)$ & 2.67 & 1.37 & 1545 & 58.7 & 35 & 65 & 100 & 6.65 & コンクリート強度試験 \\
\hline
\end{tabular}




\section{（2）高炉スラグ細骨材がコンクリートのコンシステ ンシーに及ぼす影響}

a）モルタルのコンシステンシー

表一7の A の高炉スラグ砕砂 と高炉スラグ空研砂を 使用したモルタルのコンシステンシーと，この高炉スラ グ細骨材とまったく同一の粒度に調整した川砂 (1)，(2) を使用したモルタルのコンシステンシーとを比較した. 試験にあたっては，高炉スラグ砕砂を用いた場合，水セ メント比を $30,40,50,65 \%$ の 4 種, 高炉スラグ空砕 砂を用いた場合，水セメント比を 40，50，65\%の 3 種 に変え，それぞれの水セメント比において，190土5 の フロー值が得られるような配合を試的に求めた. 水セメ ント比と砂セメント比（絶対容積比）との関係は, 図一 6 のごとくであって, このコンシステンシーのモルタル を得るに必要な配合注，水セメント比 $40 \%$ 以下の場合 には，高炉スラグ細骨材でも川砂とほとんど同じである が, 水セメント比が 50\% 以上の場合には, 高炉スラグ 細骨材モルタルにおいては, 砂セメント比を川砂モルタ ルより小さくし, 単位水量は, 川砂モルタルより大きく しなければならないことが認められる. 単位水量の増加 率は, 水セメント比 $50 \%$ の場合, 高炉スラグ砕砂使用 で 4\%, 高炉スラグ空确砂使用で $3 \%$, 水セメント比 65\% の場合, 高炉スラグ砕砂使用で 10\%, 高炉スラグ 空砕砂使用で $4 \%$ である. 水セメント比の増加に伴って 高炉スラグ研砂使用の場合に単位水量が大きくなる原因 は, フローテーブルの落下に伴いモルタルからセメント ペーストが分離し, 高炉スラグ砕砂の粒が川砂の粒より 角ばっており, 粒表面も粗であるので, 粒自身のかみ合 いの影響があるためと考えられる。これに対して，高炉 スラグ空砕砂を使用したモルタルは，水セメント比を大 きくしてもそれほど単位水量が増加しないのは, 高炉ス ラグ空砕砂粒のうち $0.6 \mathrm{~mm}$ 以上のものは, 形状が球形

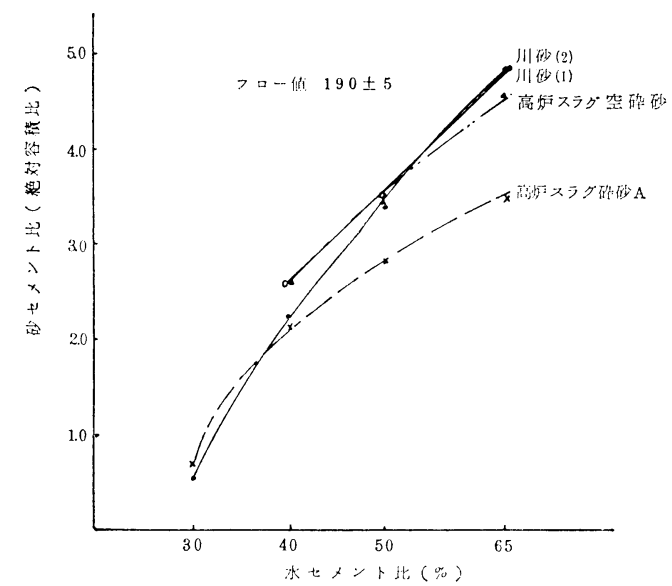

図一6 モルタルの水セメント比と砂セメント比との関係

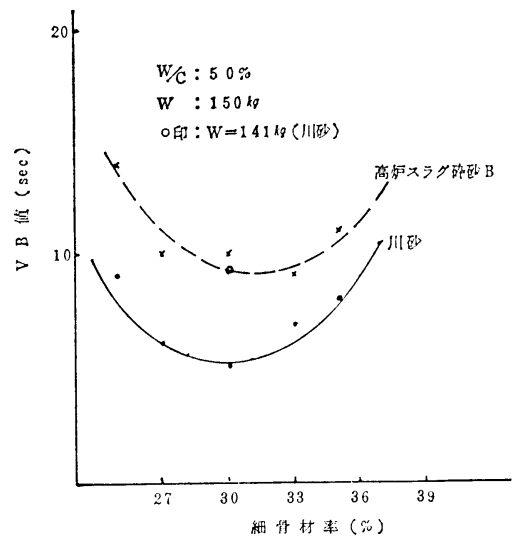

図一7 コンクリートの細骨材率と VB 值との関係

に近い丸味を呈し，粒表面も滑らかであるためである.

b) コンクリートのコンシステンシー

表一7の B の高炉スラグ砕砂, 表一8 の最大寸法 20 $\mathrm{mm}$ の川砂利を使用し, 水セメント比を $50 \%$ とし, 単 位水量を $150 \mathrm{~kg}$ に保ちながら細骨材率を順次変化させ たコンクリートの VB 試験を実施するとともに，これ と同じ配合の川砂 (1) コンクリートについても同様の試 験を行い, 両種のコンクリートにおけるコンシステンシ 一を比較検討したのである. なお川砂 (1) は，その粒度 が高炉スラグ砕砂 $\mathrm{B}$ とったく同一となるよう調整した ものを用いた．試験の結果は 図一7 のごとくである. 図一7 より VB 值が最小となる細骨材率を最適細骨材 率と考えると，高炉スラグ䂶砂コンクリートにおけるそ の值は, 川砂 (1) コンクリートの值より $2 \%$ 程度大きい 值となっている.また，水セメント比を $50 \%$ に保ちな がら川砂 (1) コンクリートの単位水量を変化させ, 高炉 スラグ砕砂コンクリートの場合と同じ VB 值を得るに 必要な単位水量を試的に求めた結果は $141 \mathrm{~kg}$ となり, 同じコンシステンシーを得るためには, 高炉スラグ砕砂 コンクリートの単位水量を川砂 (1) コンクリートより 6\% 程度大きくすることが確かめられた. これは高炉ス ラグ砕砂の粒が川砂 (1) の粒より角ばっており，粒表面 も粗であることによるものである. 一方高炉スラグ空砕 砂コンクリートにおいて表一8の川砂利を用い水セメン ト比 $65 \%$ で川砂 (2) コンクリートと同じコンシステン シーのコンクリートが得られる細骨材率, 単位水量は, 川砂 (2) コンクリートに比べて, それぞれ $3 \%, 5 \%$ の減 となっている.これは, 高炉スラグ空砕砂の粗粒分が丸 味を呈し, 粒表面も平滑であることによるものである.

\section{（3）高炉スラグ細骨材がコンクリートの強度に及ぼ す影響}

粗骨材に 表一8に示寸砕石（1），(2)を用い，細骨材 
に表一7 亿示寸高炉スラグ砕砂 $\mathrm{A}$ および B, 高炉スラグ 空砕砂ならびに川砂 (1), (2) を用い, 高炉スラグ砕砂コ ンクリートは水セメント比を 40,50，65\% の3 段階に 変化させ, 高炉スラグ空砕砂コンクリートは水セメント 比を $65 \%$ についてそれぞれスランプ值が $8 \pm 2 \mathrm{~cm} の$ コンクリートが得られるような配合を試的に定为, その 配合のコンクリートについて強度を試験した。圧縮供試 体は, 直径 $10 \mathrm{~cm}$, 高さ $20 \mathrm{~cm}$ の円柱形, 引張供試体 は, 直径 $15 \mathrm{~cm}$, 高さ $15 \mathrm{~cm}$ の円柱形, 曲げ供試体は, $10 \times 10 \times 40 \mathrm{~cm}$ の角柱であって, それぞれ JIS に準じ て材令 28 日, 91 日扮よび一部 35 週で試験を行った. それらの結果は表一9のごとくである. 表一9上り高炉

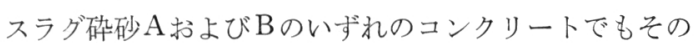
圧縮強度は水セメント比が $50 \%$ より小さい場合には, 川砂 (1) コンクリートに比べて各材令とも小さく約 90 \% であるが，水セメント比が 65\% の場合には，110 130\% となり, 川砂 (1) コンクリートより大きい值が示 された. 高炉スラグ空砕砂コンクリートでは, 各材令と も川砂 (2) コンクリートより小さい值を示している.し かし長期材令になると川砂 (2) コンクリートとほとんど 同じ值となっている. 高炉スラグ砕砂コンクリートの引 張強度も圧縮強度の場合と同様の傾向が示されている. 高炉スラグ空砕砂コンクリートの曲げ強度は, 材令 28 日までは川砂（2）コンクリートより小さいが, 材令 91 日以後では, 川砂 (2) コンクリートより $13 \%$ も強度が

表一9 各種細骨材を使用したコンクリートの 強度および強度比

\begin{tabular}{|c|c|c|c|c|c|c|c|c|}
\hline \multirow{2}{*}{$\begin{array}{l}\text { 細骨材の } \\
\text { 種 類 }\end{array}$} & \multirow{2}{*}{$\begin{array}{c}\text { 水七㙂 } \\
\text { ント比 } \\
(\%)\end{array}$} & \multirow{2}{*}{$\begin{array}{c}\text { 細骨材率 } \\
(\%)\end{array}$} & \multirow{2}{*}{$\begin{array}{l}\text { スララン } \\
\text { プ 值 } \\
(\mathrm{cm})\end{array}$} & \multicolumn{3}{|c|}{$\begin{array}{c}\text { 圧 縮 強 } \\
\left(\mathrm{kg} / \mathrm{cm}^{2}\right)\end{array}$} & \multicolumn{2}{|c|}{$\begin{array}{l}\text { 引張強度 } \\
\left(\mathrm{kg} / \mathrm{cm}^{2}\right)\end{array}$} \\
\hline & & & & 7 日 & 28 日 & 91 日 & 28 日 & 91 日 \\
\hline \multirow{3}{*}{ A } & 40 & 45 & 8.7 & $\begin{array}{c}340 \\
(91)\end{array}$ & $\begin{array}{c}411 \\
(80)\end{array}$ & $\begin{array}{c}497 \\
(84)\end{array}$ & $\begin{array}{l}31.6 \\
(90)\end{array}$ & $\begin{array}{l}37.0 \\
(98)\end{array}$ \\
\hline & 50 & 47 & 7.4 & $\begin{array}{c}259 \\
(95)\end{array}$ & $\begin{array}{c}388 \\
(96)\end{array}$ & $\begin{array}{c}444 \\
(93)\end{array}$ & $\begin{array}{l}26.1 \\
(96)\end{array}$ & $\begin{array}{l}29.7 \\
(102)\end{array}$ \\
\hline & 65 & 51 & 6.2 & $\begin{array}{c}196 \\
(148)\end{array}$ & $\begin{array}{c}258 \\
(103)\end{array}$ & $\begin{array}{c}384 \\
(130)\end{array}$ & $\begin{array}{l}21.8 \\
(100)\end{array}$ & $\begin{array}{l}28.2 \\
(112)\end{array}$ \\
\hline \multirow{3}{*}{ B } & 40 & 40 & 9.5 & $\begin{array}{r}329 \\
(88)\end{array}$ & $\begin{array}{c}453 \\
(88)\end{array}$ & $\begin{array}{l}523 \\
(89)\end{array}$ & $\begin{array}{l}33.2 \\
(95)\end{array}$ & $\begin{array}{l}33.8 \\
(90)\end{array}$ \\
\hline & 50 & 42 & 6.7 & $\begin{array}{r}237 \\
(86)\end{array}$ & $\begin{array}{c}377 \\
(93)\end{array}$ & $\begin{array}{r}440 \\
(92)\end{array}$ & $\begin{array}{l}28.7 \\
(105)\end{array}$ & $\begin{array}{l}30.5 \\
(104)\end{array}$ \\
\hline & 65 & 42 & 8.9 & $\begin{array}{r}154 \\
\text { (117) }\end{array}$ & $\begin{array}{c}273 \\
(109)\end{array}$ & $\begin{array}{c}364 \\
(123)\end{array}$ & $\begin{array}{l}23.0 \\
(106)\end{array}$ & $\begin{array}{l}29.4 \\
\text { (117) }\end{array}$ \\
\hline \multirow{3}{*}{ 川砂 (1) } & 40 & 50 & 8.2 & $\begin{array}{r}375 \\
(100)\end{array}$ & $\begin{array}{c}514 \\
(100)\end{array}$ & $\begin{array}{r}590 \\
(100)\end{array}$ & $\begin{array}{l}35.0 \\
(100)\end{array}$ & $\begin{array}{l}37.6 \\
(100)\end{array}$ \\
\hline & 50 & 55 & 6.0 & $\begin{array}{c}274 \\
(100)\end{array}$ & $\begin{array}{c}405 \\
(100)\end{array}$ & $\begin{array}{c}476 \\
(100)\end{array}$ & $\begin{array}{l}27.3 \\
(100)\end{array}$ & $\begin{array}{l}29.2 \\
(100)\end{array}$ \\
\hline & 65 & 55 & 8.6 & $\begin{array}{c}132 \\
(100)\end{array}$ & $\begin{array}{c}250 \\
(100)\end{array}$ & $\begin{array}{r}296 \\
(100)\end{array}$ & $\begin{array}{l}21.7 \\
(100)\end{array}$ & $\begin{array}{l}25.2 \\
(100)\end{array}$ \\
\hline
\end{tabular}

粗骨材は表-8 の碎石 (1), （）内强度比\%

\begin{tabular}{|c|c|c|c|c|c|c|c|c|c|c|c|}
\hline \multirow{2}{*}{$\begin{array}{l}\text { 細骨材 } \\
\text { の種燍 }\end{array}$} & \multirow{2}{*}{\begin{tabular}{|l|} 
水七尼 \\
$=\vdash$ 比 \\
$(\%)$
\end{tabular}} & \multirow{2}{*}{$\begin{array}{l}\text { 細骨 } \\
\text { 材率 } \\
(\%)\end{array}$} & \multirow{2}{*}{$\mid$\begin{tabular}{l|} 
スラン \\
$7^{\circ}$ \\
(cm) \\
$(\mathrm{cm})$
\end{tabular}} & \multicolumn{4}{|c|}{ 圧縮強度 $\left(\mathrm{kg} / \mathrm{cm}^{2}\right)$} & \multicolumn{4}{|c|}{ 曲げ強度 $\left(\mathrm{kg} / \mathrm{cm}^{2}\right)$} \\
\hline & & & & 7 日 & 28日 & 91日 & 35 週 & 7 日 & 28日 & 91日 & 35 週 \\
\hline 空砕 & 65 & 40 & 0 & $\begin{array}{l}92 \\
(83)\end{array}$ & $\begin{array}{c}162 \\
(75)\end{array}$ & $\left|\begin{array}{c}280 \\
(96)\end{array}\right|$ & $\left|\begin{array}{c}337 \\
(100)\end{array}\right|$ & $\mid \begin{array}{l}22 \\
(79)\end{array}$ & $\mid \begin{array}{l}41 \\
(98)\end{array}$ & $\begin{array}{c}54 \\
(113)\end{array}$ & $\begin{array}{c}63 \\
(126)\end{array}$ \\
\hline 川砂 & 65 & 43 & 8.0 & $\begin{array}{l}111 \\
(100)\end{array}$ & $\begin{array}{l}217 \\
(100)\end{array}$ & $\left|\begin{array}{c}293 \\
(100)\end{array}\right|$ & $\left|\begin{array}{c}338 \\
(100)\end{array}\right|$ & $\begin{array}{c}28 \\
(100)\end{array}$ & $\begin{array}{c}42 \\
(100)\end{array}$ & $\begin{array}{c}48 \\
(100)\end{array}$ & $\begin{array}{c}50 \\
(100)\end{array}$ \\
\hline
\end{tabular}

粗骨材は表一8 の砕石 (2), ( ) 内強度比 \%

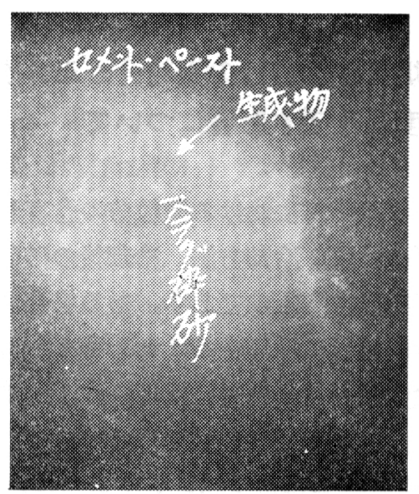

(W/C 65\%, 村令 91 日, スラケ砕砂 $\mathrm{A}$ の場合)

写真一2 スラグ砕砂粒界面部の検鏡結果の 1 例 $(\times 160)$

大きくなっている.これらの関係は, セメントペースト の強さと細骨材粒の強さとの関連, 粒形状や粒表面組織 の相違および長期材令における高炉スラグ細骨材の潜在

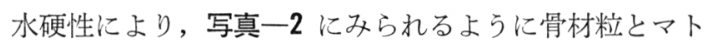
リックスとの界面に水和生成物ができ, 界面の組織が密 になったためと考えられる.

各種細骨材の粒自身の強さを検討するため, 各細骨材 をあらかじめ, $0.15 \sim 0.3 \mathrm{~mm}, 0.3 \sim 0.6 \mathrm{~mm}, 0.6 \sim 1.2$ $\mathrm{mm}, 1.2 \sim 2.5 \mathrm{~mm}$ の粒径淿るい分けておき, 各粒径 のものを鋼製円筒容器に一定量つめ, 荷重 $15 \mathrm{t}$ を載荷 し, その後もとの寸法のふるいでふるい, その通過分を 重量百分率で示したものが図一8である. 図一8より高 炉スラグ砕砂の粒自身の強さは, 粒径が $0.6 \mathrm{~mm}$ 以下 のものは, 川砂粒よりわずか代さいが, $0.6 \mathrm{~mm}$ 以上 のものは, 川砂粒に比べてかなり劣ることが認められ る. 高炉スラグ空砕砂の粒自身の強さは, 川砂粒と大差 のないものであることが認められる。

以上より, 水セメント比が小さい場合には, 粒の弱い ことが潜在水硬性による強度増加を低減しているのであ る.

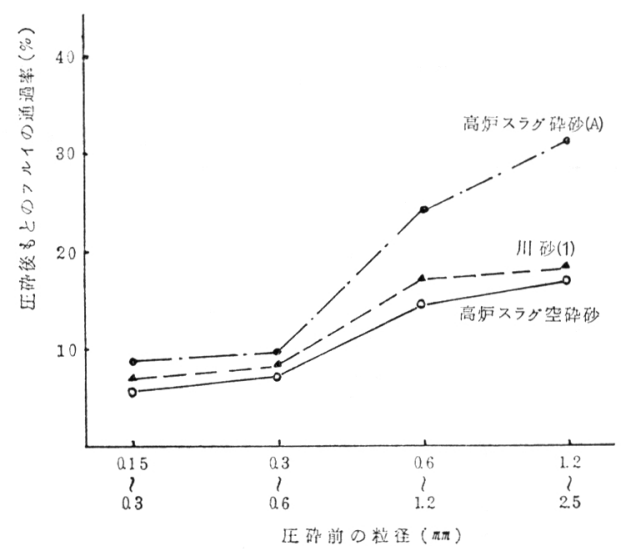

図一8 圧砕による粒径の変化 


\section{4. 高訿スラグ砕砂の微粒分がモルタル 強度に及ぼす影響について}

高炉スラグ細骨材における微粒分の含有量は, 高炉スラグの品質, 冷却方法, 冷却後の破砕方法 等によって相違するものであり，ある場合には， 微粒分の量が相当に増加することも考えられるの で, 微粒分の含有量を種々に変化させて実験を行 った.

表一10の $\mathrm{KK}$ シリーズに示すように, 0.15 $\mathrm{mm}$ ふるい以上の粒を川砂とし， $0.15 \mathrm{~mm}$ ふる い未満の微粒分を高炉スラグ砕砂とした複合細骨 材を用いたモルタルの強度を試験したのである が，微粒分の含有率を $30,20,10,5,0 \%$ の 5 種に変化させたのである.モルタルは, 水セメント比を $50 \%$ とし，フロー值が $190 \pm 5$ となるような配合を定 め, この配合のモルタルの曲げ強度ならびに圧縮強度を $4 \times 4 \times 16 \mathrm{~cm}$ の角柱供試体によって試験した. さらに 表一10の SK シリーズに示すように高炉スラグ砕砂だ けを用いて $0.15 \mathrm{~mm}$ ふるい未満の微粒分を $30 \sim 0 \%$ の

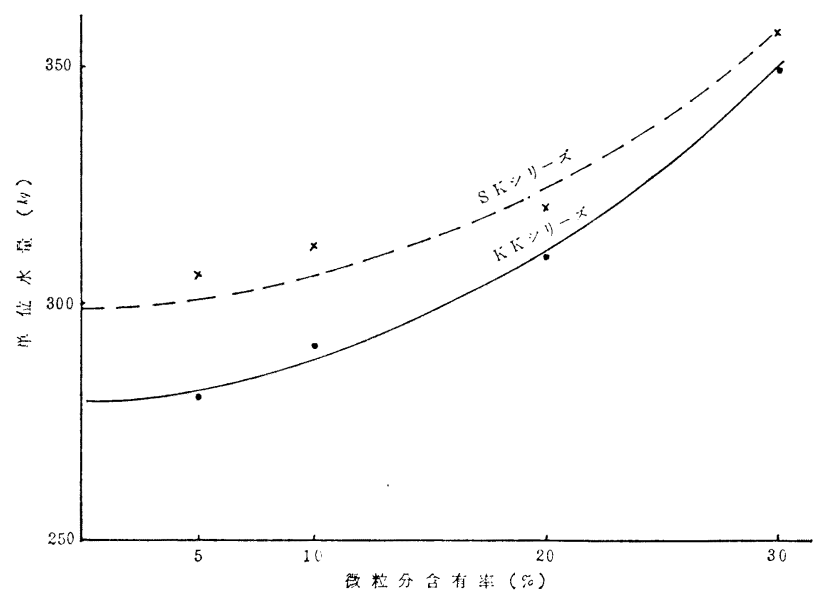

図ー9 高炬スラグ微粒分含有率とモルタルの単位水量との関係

表-10 細骨材 $の$ 物理的性質

\begin{tabular}{|c|c|c|c|c|c|c|c|c|c|c|c|}
\hline \multirow{2}{*}{ ンリーズ名 } & \multirow{2}{*}{ 種 } & \multirow{2}{*}{ 表乾比重 } & \multirow{2}{*}{$\begin{array}{c}\text { 吸水率 } \\
(\%)\end{array}$} & \multicolumn{6}{|c|}{ 川砂・粒度 (尓るいにとどちるるのの重量百分率 $)(\mathrm{mm})$} & \multirow{2}{*}{ 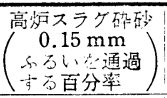 } & \multirow{2}{*}{ 租籸率 } \\
\hline & & & & 5.0 & 2.5 & 1.2 & 0.6 & 0.3 & 0.15 & & \\
\hline \multirow{5}{*}{$\underset{\text { シリーズ }}{K}$} & A & 2.68 & 1.20 & 0 & 0 & 5 & 22 & 50 & 70 & 30 & 1.47 \\
\hline & B & 2.66 & 1.30 & 0 & 0 & 20 & 40 & 60 & 80 & 20 & 2.00 \\
\hline & $\mathrm{C}$ & 2.63 & 1.40 & 0 & 0 & 30 & 65 & 80 & 90 & 10 & 2.65 \\
\hline & $\mathrm{D}$ & 2.60 & 1.60 & 0 & 0 & 33 & 70 & 85 & 95 & 5 & 2.83 \\
\hline & $\mathrm{E}$ & 2.59 & 1.90 & 0 & 0 & 36 & 75 & 90 & 100 & 0 & 3.01 \\
\hline \multirow{5}{*}{ 於リーズ } & A & 2.76 & 1.30 & \multirow{5}{*}{\multicolumn{8}{|c|}{$\mathrm{SK} \mathrm{K}$ ンリーズの粒度分布法， $\mathrm{I}$}} \\
\hline & B & 2.72 & 1.70 & & & & & & & & \\
\hline & $\mathrm{C}$ & 2.70 & 1.90 & & & & & & & & \\
\hline & $\mathrm{D}$ & 2.69 & 2.00 & & & & & & & & \\
\hline & $\mathrm{E}$ & 2.66 & 2.40 & & & & & & & & \\
\hline
\end{tabular}




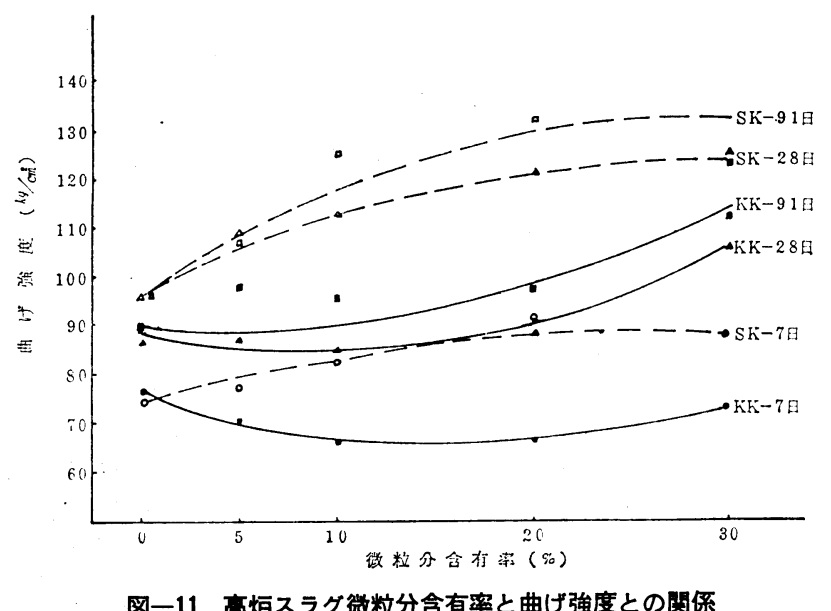

図一11 高炬スラグ微粒分含有率と曲げ強度との関係

ている.これは, 微粒分のもつ潜在水硬性と微粒分の表 面組織等の影響と考えられる。また曲げ強度は 図一11 より材令 28 日以後で微粒分の含有率が $30 \%$ となると強 度の増加は，含有率 0\%に対して $21 \sim 29 \%$ となってい る.これも圧縮強度の場合と同様な影響と考えられる.

次に図一10より SK シリーズの圧縮強度を検討する と, 各材令とも微粒分の含有率が多くなるほど強度の増 加が認められる. 材令 28 日以後では, 微粒分の含有率 が $20 \%$ となると強度の増加が著しくなり, 微粒分の含 有率 $0 \%$ に対して約 $30 \%$ の強度増加が示されている.

これは, 高炉スラグ砕砂粒の大きさがモルタルの強度 に及ぼす影響によるものである．粗粒の高炉スラグ砕砂 は, 図一8 の結果からも粒自身が弱いので, 微粒分の含 有率 $0 \%$ の場合の強度が最も小さくなったのである.

微粒分の含有率が多くなるほど強度增加を示したの は，微粒分が $0.6 \mathrm{~mm}$ 以上の粒自身の弱さが及ぼす徳 影響を緩和するためと考えられる。

図一10 により，KK シリーズと SK シリーズとを各 微粒分の含有率によって比較すると, 圧縮強度では, 含 有率が $0 \%$ において各材令とも SK シリーズの方が小 さい強度となっている.これは, 高炉スラグ砕砂の粒が 川砂粒に比べて脆弱であることによるものである．しか し微粒分の含有率が多くなると SK シリーズの方が大 きい強度となることが示されており, その強度差は, 含 有率 $20 \%$ で最大となっている. 曲げ強度については, 図一11 より，微粒分の含有率が $0 \%$ の場合でも SK シ リーズの強度が材令 7 日を除いて大きく, 含有率 $20 \%$ では, $\mathrm{KK}$ シリーズに比べて材令 91 日で約 $34 \%$ も大 きいことが示されている.

\section{5. 高师スラグ砕砂の潜在水硬性}

高炬スラグ微粉末の潜在水硬性に関しては, 結晶学
的, 化学的な研究が実施され, その結果に基づい て,これを高炉セメントの原料として用いるため の研究が進められており, その塩基度, 粉末度, 混合量ならびにポルトランドセメントクリンカー の品質および粉末度等については, ある程度の成 案が得られている. しかしこれをコンクリート用 混和材として用いるための研究は, 小林ら ${ }^{10)} に よ$ る研究のほか数も少なく, 丸安ら ${ }^{9)}$ が高炉スラグ 粉末度をブレーン值 $3800 \mathrm{~cm}^{2} / \mathrm{g}$ のものを用い， セメントとの置換率を 0 90\% に変化させたモル タルにおいて強度試験を材令 3 日〜 1 年までにつ いて行っている.これによると高炉スラグ微粉末 を混合したものは, 材令が経過するにつれて, 強 さが大きくなり, 高炉スラグの潜在水硬性は, 材 令 3 日から徐々に発揮され, 材令 28 日以降の効果が大 きいと述べている. 本研究は, 高炉スラグ砕砂の潜在水 硬性を現象的に確認するため, 高炉スラグ砕砂の種々の 粒径のものを結合素材とみなし，これでセメントの一部 と置き換えた場合のモルタルの強度についても実験を行 い，高炬スラグ砕砂粒の潜在水硬性を検討したものであ る.

セメントの置換率は，重量比で $50 \%$ および $20 \%$ と し，水一セメント・スラグ重量比を $50 \%$ ，フロー值 190 \pm 5 が得られる配合を定め, $4 \times 4 \times 16 \mathrm{~cm}$ の角柱供試体 で曲げ強度, 圧縮強度の試験を行った. 高炉スラグ砕砂 をふるい分け, $0.15 \mathrm{~mm}$ 子るい未満, $0.15 \sim 0.3 \mathrm{~mm}$, $0.3 \sim 0.6 \mathrm{~mm}, 0.6 \sim 1.2 \mathrm{~mm}, 1.2 \sim 2.5 \mathrm{~mm}$ の 5 種のも のとし, これらを用いて，それぞれセメントの一部を直 き換えた。これらは，絶乾状態で使用した．なお比較の ために, セメント試験用標準砂を粉砕した $0.15 \mathrm{~mm}$ 末 満および, $0.15 \sim 0.3 \mathrm{~mm}$ の粒径のものについても置換 率, 配合等を同一として試験を行った。またモルタルの 細骨材としては，表一7に示した川砂（1）を使用した. 試験結果は，表一11，図一12 のごとくである.

表一11 より粒径 $0.3 \mathrm{~mm}$ 以上の高炉スラグ砕砂を置 き換えたモルタルは, 圧縮強度, 曲げ強度において, 各 粒径での強度差はほとんどないが, 粒径 $0.3 \mathrm{~mm}$ 末満 の高炉スラグ砕砂を置き換えたモルタルの圧縮強度なら びに曲げ強度は，粒径が小さくなるほど増加する傾向が 示されており，材令 91 日ほどその傾向が大である.す なわち高炉スラグ砕砂の潜在水硬性は，粒径が小さいほ ど発揮されると考えられる。

表一11, 図一12 より $0.3 \mathrm{~mm}$ 末満の粒について高炉 スラグ砕砂粉末をセメントの一部として置き換えたモル タルと, 標準砂粉末をセメントの一部として置き換えた モルタルの強度について比較すると, 置換率 $50 \%$, 置 換率 $20 \%$ のいずれの場合も, 各強度とも高炉スラグ砕 
表一11 各粒径の細骨材で置き換えたモルタルの強度

（）内強度比 \%

\begin{tabular}{|c|c|c|c|c|c|c|c|c|c|c|c|c|c|c|c|c|}
\hline \multirow{3}{*}{\multicolumn{2}{|c|}{ 種 }} & & & 率 (\%) & \multicolumn{6}{|c|}{50} & \multicolumn{6}{|c|}{20} \\
\hline & & & & 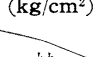 & \multicolumn{3}{|c|}{ 圧縮 強 度 } & \multicolumn{3}{|c|}{ 曲げ強度 } & \multicolumn{3}{|c|}{ 臣縮 強 度 } & \multicolumn{3}{|c|}{ 曲げ強度 } \\
\hline & & 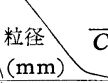 & $\bar{S}$ & 縜樍比) & 7 & 28 & 91 & 7 & 28 & 91 & 7 & 28 & 91 & 7 & 28 & 91 \\
\hline \multirow[b]{2}{*}{$\begin{array}{l}\text { 高 } \\
\text { 炉 }\end{array}$} & A & $1.2 \sim 2.5$ & 50 & $\begin{array}{l}1.40 \\
1.49\end{array}$ & 64 & 133 & 198 & 19.2 & 32.9 & 42.8 & 227 & 388 & 417 & 53.4 & 64.6 & 74.4 \\
\hline & B & $0.6 \sim 1.2$ & 50 & $\begin{array}{l}1.44 \\
1.52\end{array}$ & 62 & 130 & 196 & 17.5 & 33.4 & 41.8 & 211 & 353 & 415 & 55.4 & 66.5 & 72.9 \\
\hline \multirow[t]{2}{*}{$\begin{array}{l}\text { र } \\
\text { j }\end{array}$} & $\mathrm{C}$ & $0.3 \sim 0.6$ & 50 & $\begin{array}{l}1.46 \\
1.53\end{array}$ & 63 & 124 & 190 & 18.7 & 33.5 & 47.1 & 210 & 334 & 408 & 55.1 & 65.0 & 76.4 \\
\hline & \multicolumn{4}{|c|}{$\mathrm{A}, \mathrm{B}, \mathrm{C}$ の平均值 } & $\begin{array}{c}63 \\
(100)\end{array}$ & $\begin{array}{c}129 \\
(100)\end{array}$ & $\begin{array}{c}195 \\
(100)\end{array}$ & $\begin{array}{l}18.5 \\
(100)\end{array}$ & $\begin{array}{l}33.3 \\
(100)\end{array}$ & $\begin{array}{l}43.9 \\
(100)\end{array}$ & $\begin{array}{c}216 \\
(100)\end{array}$ & $\begin{array}{c}358 \\
(100)\end{array}$ & $\begin{array}{c}413 \\
(100)\end{array}$ & $\begin{array}{l}53.3 \\
(100)\end{array}$ & $\begin{array}{l}65.4 \\
(100)\end{array}$ & $\begin{array}{l}74.6 \\
(100)\end{array}$ \\
\hline \multirow[t]{2}{*}{$\begin{array}{l}\text { 砕 } \\
\text { 砂 }\end{array}$} & $\mathrm{D}$ & $0.15 \sim 0.3$ & 50 & $\begin{array}{l}1.51 \\
1.55\end{array}$ & $\begin{array}{c}65 \\
(103)\end{array}$ & $\begin{array}{c}148 \\
(115)\end{array}$ & $\begin{array}{c}224 \\
(115)\end{array}$ & $\begin{array}{l}20.7 \\
\text { (112) }\end{array}$ & $\begin{array}{l}35.6 \\
(107)\end{array}$ & $\begin{array}{l}50.8 \\
(116)\end{array}$ & $\begin{array}{c}212 \\
(98)\end{array}$ & $\begin{array}{c}386 \\
(108)\end{array}$ & $\begin{array}{c}417 \\
(101)\end{array}$ & $\begin{array}{l}52.7 \\
(99)\end{array}$ & $\begin{array}{l}68.1 \\
(104)\end{array}$ & $\begin{array}{l}76.9 \\
(103)\end{array}$ \\
\hline & $\mathrm{E}$ & 0.15 末満 & 50 & $\begin{array}{l}1.51 \\
1.55 \\
\end{array}$ & $\begin{array}{c}94 \\
(149)\end{array}$ & $\begin{array}{l}197 \\
(153)\end{array}$ & $\begin{array}{c}323 \\
(166)\end{array}$ & $\begin{array}{l}25.8 \\
(139)\end{array}$ & $\begin{array}{l}50.2 \\
(151)\end{array}$ & $\begin{array}{l}54.9 \\
(125) \\
\end{array}$ & $\begin{array}{c}238 \\
(110)\end{array}$ & $\begin{array}{c}389 \\
(109)\end{array}$ & $\begin{array}{c}475 \\
(115)\end{array}$ & $\begin{array}{l}49.8 \\
(93)\end{array}$ & $\begin{array}{l}73.2 \\
(112) \\
\end{array}$ & $\begin{array}{l}80.1 \\
(107)\end{array}$ \\
\hline \multirow{2}{*}{$\begin{array}{l}\text { 標 } \\
\text { 準 } \\
\text { 砂 }\end{array}$} & $\mathrm{D}^{\prime}$ & $0.15 \sim 0.3$ & 50 & $\begin{array}{l}1.43 \\
1.52 \\
\end{array}$ & $\begin{array}{r}59 \\
(94) \\
\end{array}$ & $\begin{array}{c}131 \\
(102)\end{array}$ & $\begin{array}{c}180 \\
(92) \\
\end{array}$ & $\begin{array}{l}19.4 \\
(105)\end{array}$ & $\begin{array}{l}33.1 \\
(99)\end{array}$ & $\begin{array}{l}44.7 \\
(102) \\
\end{array}$ & $\begin{array}{c}153 \\
(71) \\
\end{array}$ & $\begin{array}{c}309 \\
(86) \\
\end{array}$ & $\begin{array}{c}428 \\
(104)\end{array}$ & $\begin{array}{l}38.9 \\
(73)\end{array}$ & $\begin{array}{l}60.4 \\
(92)\end{array}$ & $\begin{array}{l}71.6 \\
(96)\end{array}$ \\
\hline & $E^{\prime}$ & 0.15 末満 & 50 & $\begin{array}{l}1.44 \\
1.51\end{array}$ & $\begin{array}{c}80 \\
(127)\end{array}$ & $\begin{array}{c}152 \\
(118)\end{array}$ & $\begin{array}{c}200 \\
(103)\end{array}$ & $\begin{array}{l}25.4 \\
(137)\end{array}$ & $\begin{array}{l}38.3 \\
\text { (115) }\end{array}$ & $\begin{array}{l}48.4 \\
(110)\end{array}$ & $\begin{array}{c}166 \\
(77)\end{array}$ & $\begin{array}{c}337 \\
(94)\end{array}$ & $\begin{array}{c}441 \\
(107)\end{array}$ & $\begin{array}{l}42.4 \\
(80)\end{array}$ & $\begin{array}{c}64.4 \\
(98)\end{array}$ & $\begin{array}{l}72.6 \\
(97)\end{array}$ \\
\hline \multirow{2}{*}{\multicolumn{2}{|c|}{$\begin{array}{l}\text { 強 } \\
\text { 比 } \\
\%\end{array}$}} & $\frac{\mathrm{D}}{\mathrm{D}^{\prime}}$ & 標準石 & $\frac{8 \pi}{\text { タル }}$ & 110 & 113 & 124 & 108 & 108 & 114 & 139 & 125 & 97 & 135 & 113 & 107 \\
\hline & & $\frac{E}{E^{\prime}}$ & $\begin{array}{l}\text { スラ } \\
\text { 標準碍 }\end{array}$ & ルタル & 116 & 130 & 166 & 102 & 131 & 113 & 143 & 115 & 108 & 117 & 114 & 110 \\
\hline
\end{tabular}
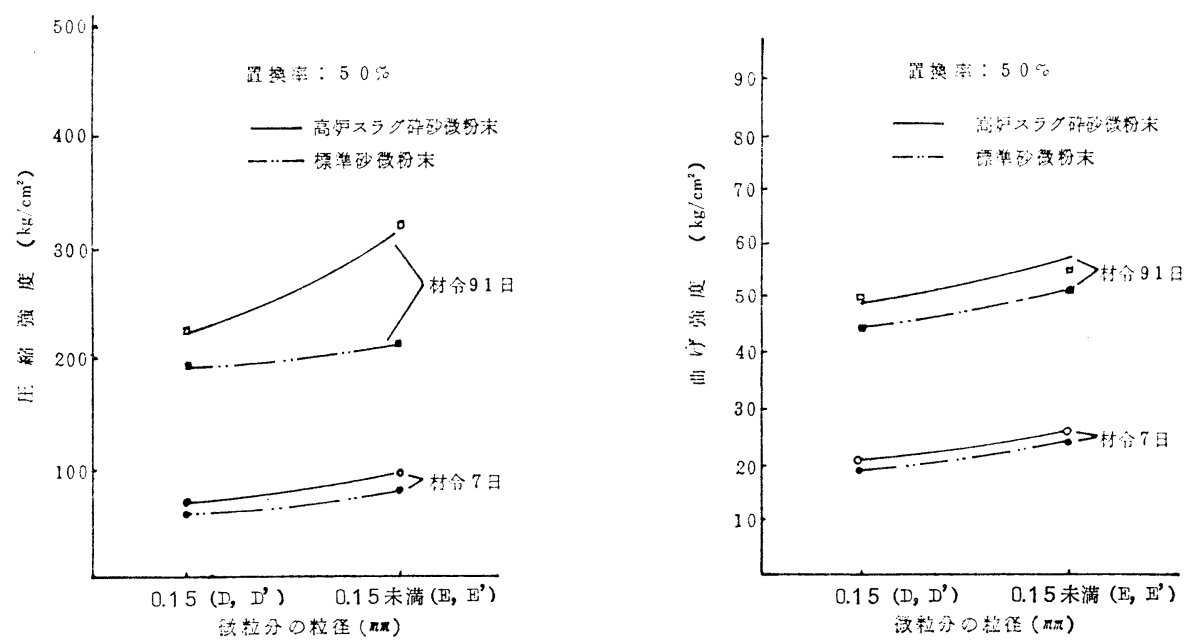

図一12 置き換えた微粒分の粒径とモルタルの強度との関係

砂粉末を置き換えたモルタルの方が大きい值を示してい る.これらは，高炉スラグ砕砂の潜在水硬性によるもの であるが， $0.15 \mathrm{~mm}$ 末満の高炬スラグ微粉末のブレー ン值が $1240 \mathrm{~cm}^{2} / \mathrm{g}$ である粗い粉末であっても，これだ けの効果が示されたことは，注目すべきである.

上述より高炉スラグ微粉末をコンクリート用混和材と して利用し，セメントを節約することができると思われ る. 高炉スラグ砕砂を粉砕した微粉末をコンクリート用 混和材として利用するには，その高炉スラグ微粉末の粉 末度, 置換率がコンクリートの構造物に適した值となる
ように選定することが問題と考えられる.

そこで高炉スラグ微粉末を混和材としてコンクリート に用い実験を重ねた。 すなわち 表一12 に示すように化 学成分がほとんど同じで, 高炉スラグ微粉末の粉末度が ブレーン值で $2500 \mathrm{~cm}^{2} / \mathrm{g}$ および $4100 \mathrm{~cm}^{2} / \mathrm{g}$ と大差の ある 2 種類のものを使用し, セメントの置換率を絶対容 積比で $0,30,50,70 \%$ の 4 種に変化させ, 水一セメン ト・スラグ比を $60 \%$ ， スランプ $8 \mathrm{~cm}$ のコンクリート が得られるような配合を定めた。使用した骨材は 表一 13 のものである. 配合を決定するに先立って，コンク 
表一12 高炉スラグ微粉末の化学成分

\begin{tabular}{|c|c|c|c|c|c|c|c|c|c|c|}
\hline & \multirow{2}{*}{ 比重 } & \multirow{2}{*}{$\begin{array}{c}\text { 此表面積 } \\
\text { フ } \\
\left(\mathrm{cm}^{2} / \mathrm{g}\right)\end{array}$} & \multicolumn{3}{|c|}{ 化 } & 成 & \multicolumn{3}{|c|}{$(\%)$} & \multirow{2}{*}{ 塩基度 } \\
\hline & & & $\mathrm{SiO}_{2}$ & $\mathrm{Al}_{2} \mathrm{O}_{3}$ & $\mathrm{Fe}_{2} \mathrm{O}_{3}$ & $\mathrm{CaO}$ & $\mathrm{SO}_{2}$ & $\mathrm{MgO}$ & ig. Loss & \\
\hline 高洷スラク微粉末（A） & 2.82 & 2500 & 31.7 & 16.8 & 0.4 & 40.4 & 0.1 & 5.2 & 0.1 & 1.97 \\
\hline 高炉スラク微粉末（B） & 2.92 & 4100 & 33.4 & 15.5 & 0.6 & 40.8 & 0.1 & 7.0 & 0.1 & 1.90 \\
\hline
\end{tabular}

表一13 骨材の物理試験結果

\begin{tabular}{|c|c|c|c|c|c|c|c|c|}
\hline & & \multirow{2}{*}{ 比重 } & \multirow{2}{*}{$\begin{array}{c}\text { 吸 水 率 } \\
(\%)\end{array}$} & \multirow{2}{*}{$\begin{array}{c}\text { 輍 倩㜔 } \\
(\mathrm{kg} / l)\end{array}$} & \multirow{2}{*}{$\begin{array}{c}\text { 実 績 率 } \\
(\%)\end{array}$} & \multicolumn{2}{|c|}{ 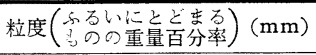 } & \multirow{2}{*}{ 粗 粒率 } \\
\hline & & & & & & $20 \sim 10$ & $10 \sim 5$ & \\
\hline 碎 & 石 & 2.67 & 1.30 & 1.55 & 58.8 & 65 & 100 & 6.65 \\
\hline
\end{tabular}

\begin{tabular}{|c|c|c|c|c|c|c|c|c|c|c|c|c|}
\hline & & \multirow{2}{*}{ 比重 } & \multirow{2}{*}{$\begin{array}{c}\text { 吸水率 } \\
(\%)\end{array}$} & \multirow{2}{*}{ 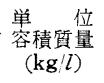 } & \multirow{2}{*}{$\begin{array}{c}\text { 実 績 率 } \\
(\%)\end{array}$} & \multicolumn{6}{|c|}{ 粒度（ふるいにとどまるものの重量百分率）（mm） } & \multirow{2}{*}{ 粗 粒率 } \\
\hline & & & & & & $5.0 \sim 2.5$ & $2.5 \sim 1.2$ & $1.2 \sim 0.6$ & $0.6 \sim 0.3$ & $0.3 \sim 0.15$ & $0.15 \sim 0$ & \\
\hline 川 & 砂 & 2.59 & 3.70 & 1.60 & 63.9 & 3 & 16 & 56 & 84 & 98 & 100 & 2.57 \\
\hline
\end{tabular}

リートのコンシステンシーについて実験を行った結果, 高炉スラグ微粉末でセメントの一部を置き換えたコンク リートでは, 置換率 $0 \%$ のコンクリートと同一スランプ を得るための細骨材率は, 粉末度, 置換率が変っても, ほぼ同じでこの場合 $43 \%$ 程度であり, 単位水量は高炉 スラグ微粉末の粉末度がブレーン值 $4100 \mathrm{~cm}^{2} / \mathrm{g}$ でセメ ントの一部を置き換えたコンクリートでは，置換率 $0 \%$ のコンクリートに比べて単位水量を若干減らすことがで きるようであり，たとえば置換率 $70 \%$ の場合には，単 位水量を $5 \%$ 程度減らすことができることが認められ た. しかし高炉スラグ微粉末の粉末度 $2500 \mathrm{~cm}^{2} / \mathrm{g}$ でセ メントの一部を $30 \%$ 置き換えたコンクリートでは, 置 換率 $0 \%$ のコンクリートと同ビスランプを得るための単 位水量注, $5 \%$ 程度大きくなり, 置換率 $50 \%$ ともなる と, $8 \%$ 程度大きくなることが認められた。

強度試験に用いたコンクリートの配合は，表一14の ごとくである.この配合のコンクリートを $20^{\circ} \mathrm{C}, 40^{\circ} \mathrm{C}$, $5^{\circ} \mathrm{C}$ の水中において所定の材令まで養生し, 圧縮試験を 行った. 供試体は直径 $10 \mathrm{~cm}$, 高さ $20 \mathrm{~cm}$ の円柱供試 体である.その結果を示したものが 図一13，14，15 で ある・

図一13 より高炉スラグ微粉末のブレーン值が相違す

表一14 高炉スラグ微粉末を用いたコンクリートの配合表

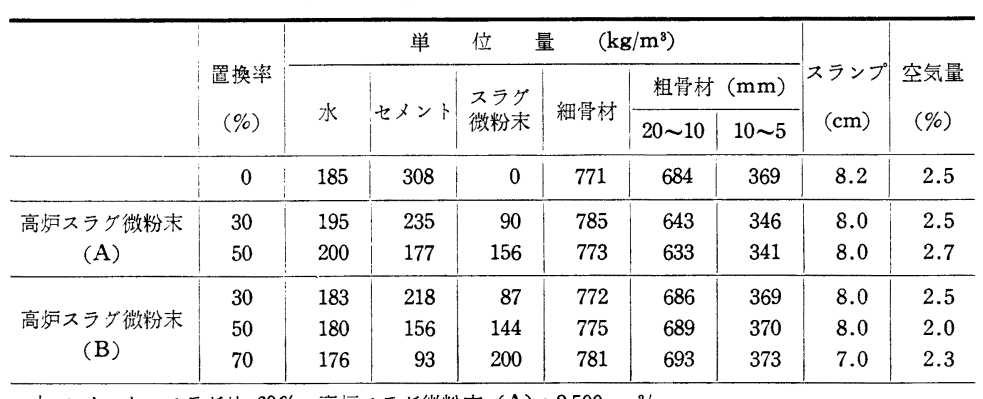

水ーセメント・スラク比 $60 \%$; 高炑スラク微粉末 (A) $: 2500 \mathrm{~cm}^{2} / \mathrm{g}$ 高炉スラグ微粉末 (B) $: 4100 \mathrm{~cm}^{2} / \mathrm{g}$
る 2 種類のもので置き換えたコンクリートの強度につい て検討する. 短期材令 7 日において, ブレーン值 4100 $\mathrm{cm}^{2} / \mathrm{g}$ の高炉スラグ微粉末でセメントの一部を置き換え たコンクリートは, 置換率 $30 \%$ で $39 \%$ 程度, 置換率 $55 \%$ で 49\%，置換率 70\% で 76\% 程度，置換率 $0 \%$ のコンクリートより強度が劣るのに対し, ブレーン值 $2500 \mathrm{~cm}^{2} / \mathrm{g}$ の高炉スラグ微粉末でセメントの一部を置 き換えたコンクリートでは, 置換率 $30 \%$ で 46\%, 置 換率 $50 \%$ では $57 \%$ 程度，置換率 $0 \%$ のコンクリート より強度が劣ることが認められた. 以上材令 7 日におけ る高炉スラグ微粉末のブレーン值が相違することによる 置換率 $0 \%$ のコンクリートに対する強度低下は, ブレ ーン值の大きい高炉スラグ微粉末を用いた場合ほど小さ いことが認められる.

材令 6 か月となると, ブレーン值 $4100 \mathrm{~cm}^{2} / \mathrm{g}$ の高炉 スラグ微粉末でセメントの $30 \%$ 置き換えたコンクリー トの強度は, 置換率 $0 \%$ のコンクリートより $6 \%$ 程度 大きく, セメントの $50 \%$ 置き換えたコンクリートの強 度は $2 \%$ 程度大きく, セメントの $70 \%$ を置き換えたコ ンクリートであっても置換率 $0 \%$ のコンクリート強度 の $85 \%$ の強度が得られる. 一方, ブレーン值 2500 $\mathrm{cm}^{2} / \mathrm{g}$ の高炉スラグ微粉末でセメントの $30 \%$ を置き換 えた場合の強度は, 置換率 $0 \%$ のコ ンクリートの $98 \%$ 程度が得られ, $50 \%$ を置き換えた場合でも $83 \%$ の 強度が得られる.

以上材令 6 か月の場合, 高炉スラ グ微粉末のブレーン值 $2500 \mathrm{~cm}^{2} / \mathrm{g}$ であっても, 置換率 0\%のコンクリ ートに対する強度は，置換率 $30 \%$ 程度まではほぼ同程度となる。これ は, 高炉スラグ微粉末のもつ潜在水 硬性が材令が経過するほど顕著とな 


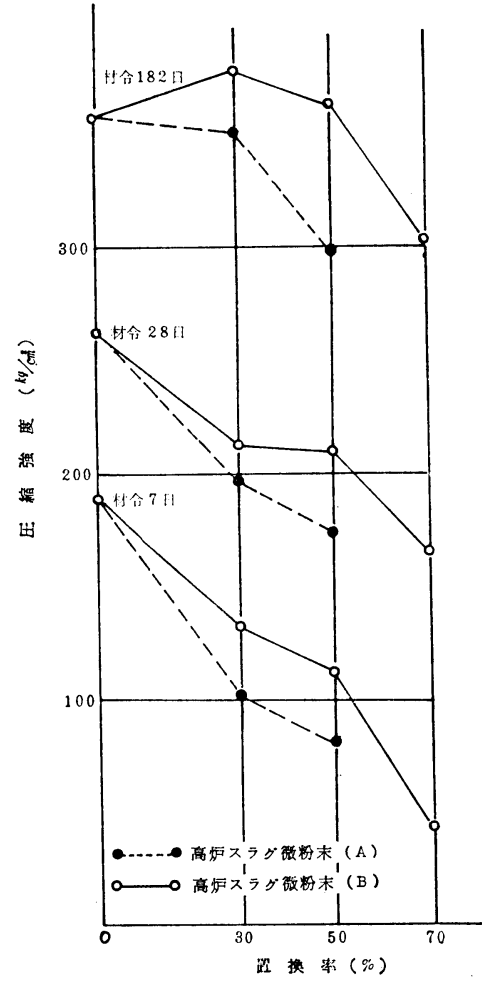

図一13目換率と圧縮強度との関係 （養生温度 $20^{\circ} \mathrm{C}$ の場合）

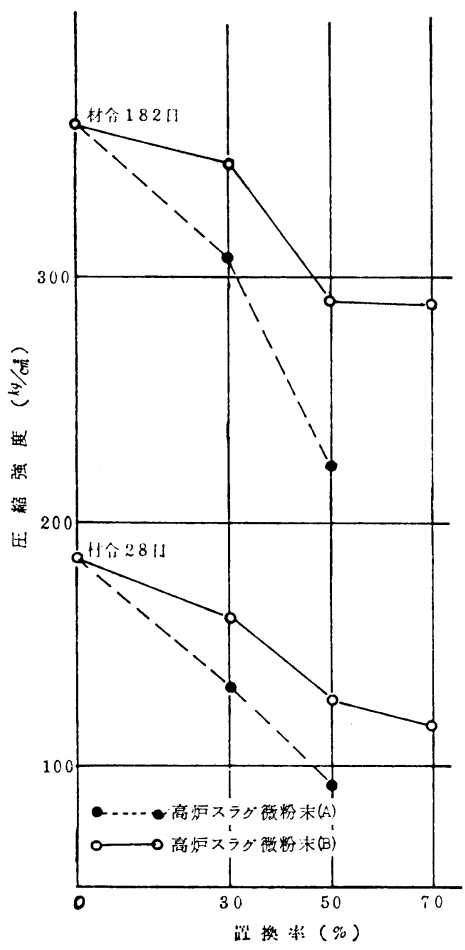

図一14置換率と圧縮強度との関係 （養生温度 $5^{\circ} \mathrm{C}$ の場合）

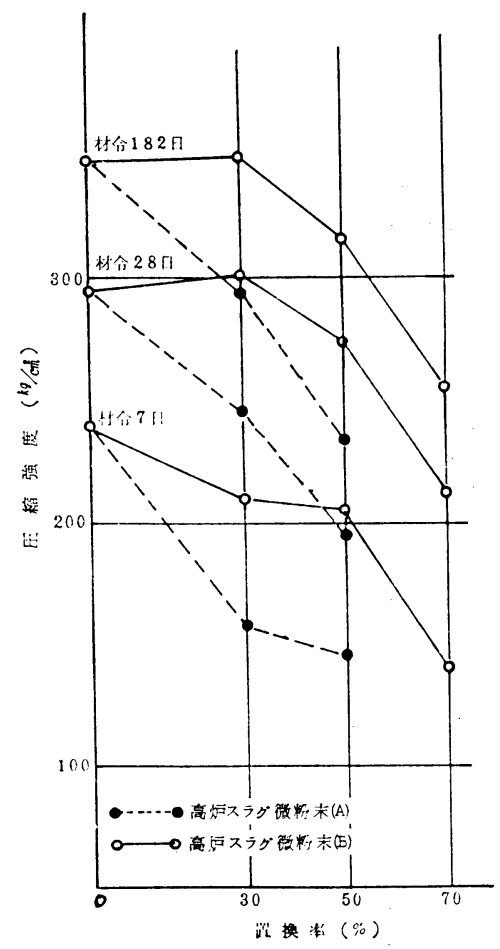

図一15四換率と圧縮強度との関係 （養生温度 $40^{\circ} \mathrm{C}$ の場合）

\section{ることを示すものである．}

上記実験結果より，高炉スラグ微粉末を混和材として セメントの一部を置き換えて用いたコンクリートの強度 は用いる高炉スラグ微粉末の粉末度, セメントとの置換 率，材令により明らかに相違することが認められた.

また高炬スラグ微粉末を混和材として用いたコンクリ 一トの強度は, 養生温度により相違することが予想され る. 一般にコンクリートを $40^{\circ} \mathrm{C}$ のような比較的高温度 で養生した場合，水和反応の速度が早くなり， $20^{\circ} \mathrm{C} て ゙$ 養生した場合に比べて初期より強度が大きくなるといわ れている ${ }^{11}$. 図一15より高炉スラグ微粉末でセメント の一部を置き換えたコンクリートにおいても同様な傾向 があり, 材令 7 日においては置換率が大きい場合に特に 著しいようである.たとえばブレーン值 $4100 \mathrm{~cm}^{2} / \mathrm{g}$ の 場合, 置換率 0\% のコンクリートでは, $40^{\circ} \mathrm{C}$ で養生し た場合の強度が $20^{\circ} \mathrm{C}$ で養生した場合の強度に比べて 26 $\%$ 程度大きいのに対し, 高炉スラグ微粉末でセメントの 一部を $30 \%$ 置き換えたコンクリートでは, $40^{\circ} \mathrm{C}$ で養 生した場合の強度 が $59 \%$ 程度大きくなり，置換率 50 \%のコンクリートでは，81\% も大きくなることが認め られた.

一方材令が 6 か月となると $40^{\circ} \mathrm{C}$ で養生した場合, 20 ${ }^{\circ} \mathrm{C}$ で養生した場合に比べてコンクリートの強度の増加
は小さくなり, 高炉スラグ微粉末でセメントの一部を㯰 き換えたコンクリートであっても，普通のコンクリート の場合と同様の傾向が認められた. これは, 養生温度が 高い場合に高炉スラグ微粉末のもつ潜在水硬性が早期の 材令より発揮され，長期の材令となると潜在水硬性は鈍 る傾向にあることを示唆するものである.

国分ら ${ }^{12)}$ は，コンクリート用混和材としてフライアッ シュを使用し, 高温度で養生したコンクリートの強度試 験を行っている.これによると，フライアッシニでセメ ントの一部を㯰き換えたコンクリートは, 高温度養生が コンクリートの長期強度に及ぼす悪影響を緩和できると 述べている. しかし高炉スラグ微粉末でセメントの一部 を置き換えたコンクリートでは, 高温度で養生した場合 長期材令となると強度の伸びが鈍くなるようである.こ の点フライアッシニを用いた場合と異なることが認めら れたのである.

また，セメントの一部を高炉スラグ微粉末で置き換え たコンクリートを $5^{\circ} \mathrm{C}$ のように低温度で養生した場合， 図一14より長期の材令となっても，置換率 0\% のコン クリートより強度が著しく劣る. 荃生温度が低い場合に は，セメントの水和速度は遅くなるのであるが，高炉ス ラグ微粉末のもつ潜在水硬性の発現も鈍くなるようであ る. 
以上より, 長期材令で強度が必要となるよらなコンク リートの場合に高炉スラグ微粉末を混和材として用いる には, 高炉スラグ微粉末の粉末度を $3000 \sim 3500 \mathrm{~cm}^{2} / \mathrm{g}$, 置換率を $50 \%$ 程度に選定すれば, 所定の品質のコンク リートの製造も可能となり，すこぶる経済的であり，有 利となる場合が多いと考えられる。 また養生温度による 影響が大きいことから, 高炉スラグ微粉末を混和材とし て用いたコンクリートでは, 養生温度に十分な注意を払 うことが必要である.

\section{6. 結 論}

わが国で現在生産されている代表的な数種の高炉スラ グを用い, これらをコンクリート用粗骨材, 細骨材なら びに混和材として利用する方法についての基礎的研究を 行った. 高炉スラグの品質は, 溶鉱炉内の製鉄原料の品 質および温度ならびに冷却方法および破砕処理方法等に より相違し, 複雑であるばかりでなく, 実験に供した高 炉スラグの数が限られているので, 明確な結論を得るに は至っていないが，実験の範囲内で次のことがいえると 思われる.

（1）高炉スラグ粗骨材の粒形は角ばり，粒の表面も 粗であるので，これを用いて同一の粒度の川砂利を使用 したコンクリートと同じコンシステンシーのコンクリー 卜を得るためには, 細骨材率を平均 $3 \%$ 大きく, 単位 水量を平均 $19 \mathrm{~kg}$ 大きくする必要のあることが示され た.

また, 高炉スラグ粗骨材粒の強度は弱く, 高炉スラグ 粗骨材の場合, すりへり減量試験值は, 川砂利の場合の 約 3 倍に達しているが，これがコンクリートの強度に及 ぼす影響澺外に小さいことが示された.すなおち水セ メント比を同一に保った場合について, 高炉スラグ粗骨 材コンクリートの圧縮, 曲げ強度を川砂利コンクリート の場合と比較した結果, 各材令において川砂利コンクリ 一トより大きいことが示された. しかし強度が大きくな る程度は, 水セメント比が大きい場合に著しくなり, 水 セメント比が $65 \%$ の場合には，材令 56 日で約 1.14 〜1.34 倍の強度に達した。 これらは高炉スラグ粗骨材 粒表面が粗であるためセメントペーストとの付着性状が 良好であることの影響が粒の弱さの悪影響を補ったこと によるものと思われる.

（2）高炉スラグ砕砂は，粒形が角ばり，粒の表面が 粗であるので，粒度をまったく同一とした川砂を用いた コンクリートと同じコンシステンシーのコンクリートを 得るためには，細骨材率を約 $2 \%$, 単位水量を約 $6 \%$ 大 きくしなければならないことが示された. 高虾スラグ空 砕砂は, 粗粒分が丸味を呈し, 粒表面も平滑であるの
で，川砂コンクリートと同じコンシステンシーのコンク リートを得るために, 細骨材率を $3 \%$, 単位水量を $5 \%$ 程度小さくすることができることが示された.

水セメント比を同一に保ったコンクリートについて, 高炉スラグ砕砂を用いた場合と川砂を用いた場合との強 度を比較すると, 水セメント比が $50 \%$ のコンクリート では, 各材令とも川砂コンクリートと同等の強度となる が水セメント比が $65 \%$ の場合には, 材令 3 か月におい て川砂コンクリートに比べて圧縮強度では約 25\% 大き く, 引張強度では約 15\% 大きい強度となる. また, 長 期材令ほど細粒分における潜在水硬性によって強度が大 きくなることが認められたのである. 高炉スラグ空砕砂 は, 初期材令において川砂コンクリート上り圧縮強度は 小さい值を示しているが，長期材令になると川砂コンク リートとほとんど同じ值となる. 曲げ強度は, 材令 91 日で川砂コンクリートより $13 \%$ 大きい值が示されてい る.

また破砕加工を行う過程において, $0.15 \mathrm{~mm}$ 末満の 微粉分が高炉スラグ細骨材中にある程度多く含まれるこ とも考えられるが，これは潜在水硬性を有する成分であ るので問題はないと思われる.

（3）高炉スラグ砕砂の潜在水硬性について, 各粒の 大きさとモルタルの強度との関連について試験を重ねた 結果, $0.3 \mathrm{~mm}$ 以上の粒を用いたモルタルにおいては, 高炉スラグ厒砂粒が弱いことの悪影響が現われ，モルタ ルの強度は低くなるが, $0.3 \mathrm{~mm}$ 未満の粒が多い場合, 特に $0.15 \mathrm{~mm}$ 未満の微粒分が多いほど, 強度が大きく なることが示された.これは, 粒自身の弱さの影響が薄 れるとともに，潜在水硬性が大きくなったことによるも のである.

（4）急冷高炉スラグ砕砂を粉砕した微粉末を混和材 としてコンクリートに用い検討した結果, セメントの置 換率が $30 \%$ 程度の場合には, スラグ微粉末の粉末度 が, ブレーン值で $2500 \mathrm{~cm}^{2} / \mathrm{g}$ 程度であっても, 材令 6 か月において，微粉末を用いないコンクリートの強度の $90 \%$ 以上の值が得られ, ブレーン值約 $4000 \mathrm{~cm}^{2} / \mathrm{g}$ の ものでは, 置換率を $70 \%$ に高めても微粉末を用いない コンクリートの強度の $85 \%$ 以上の強度が得られること が示された.これは, 高炉スラグ微粉末がコンクリート 用の混和材となり得ることを実証するものと思われる. 高炉スラグ微粉末がコンクリートにおける長期強度の増 遥, 化学的抵抗性の改善 ${ }^{13)}$ 等に役立つことは明らかであ り，これで適当量のセメントを置き換えれば，コンクリ 一トの性質の向上と, 経済性とを両立できるぼかりでな く, 硬化熱を緩和して, マスコンクリートに利用できる と考えられるのである.

わが国の最大の課題である省資源, 省エネルギーに貢 
献するための高炉スラグの活用法は，コンクリート用混 和材としての利用にあると思われるのであって，この方 面の研究がきわめて重要であろう.

本研究を行うにあたっては，國分正胤博士，小林正几 博士より終始ご㖃厚なるご指導を賜った．また，原田修 輔，北村政幸両氏には，実験に多大なるご援助をいただ いた.ここに厚くお礼申し上げます。

\section{参 考 文 献}

1）中山道輔・山崎寛司・前川 淳・秋永蕜弘：粗骨材とし ての高炉鉱サイ砤石の利用に丳する研究，セメント技術 年報, pp. 266 271, 1968.

2）吉田弥智: 高炉スラグを粗骨材として用いたコンクリー トの強度に関する基䃈研究, セメント・コンクリート, No. 260, pp. 20 26, 1968.

3）建設省土木研究所コンクリート研究室：河川砂利以外の 骨材を使用した場合のコンクリートに関する研究，第 22 回建設省技術研究会報告, pp. 1 13, 1969.

4）吉田弥智・沼田晋一：高炉スラグ砕石のコンクリート骨 材への利用に関する研究, セメント・コンクリート, No. 296, pp. 30 35, 1971.

5）林 正道：最近のコンクリート用骨材，セメント協会第
22 回コンクリート講習会テキスト, pp. 46〜 51.

6）木村恵雄：高炉スラグ砕石 および水涬を骨材とするコン クリートの配合 扩よび強度について，七メント技術年報 XII, pp. 296 303, 1958.

7）村上武衡：高炉水砕砂を用いたコンクリートについて, セメント・コンクリート, No. 349, pp. 8〜14, 1976.

8）仕入豊和・地濃茂雄 : 高炉水砕スラグのコンクリート用 細骨材への適用性に関する研究, 建築学会論文報告集第 244 号, pp. 1 12, 1976.

9）丸安隆和・小林一輔・坂本好史：高炉セメントコンクリ ートの研究, コンクリート・ライブラリー, 第 25 号, 1970.

10）小林一輔・伊藤利治：高炉水砕スラグを混合材として用 いたコンクリートの圧縮強度と乾燥収縮, 第 30 回セメ ント技術大会講演要旨, pp. 86〜87.

11）吉田德次郎：コンクリート及び 鉄筋コンクリート施工方 法, pp. 367.

12）國分正龍・三浦一郎・高野俊介・杉木六郎：養生中の温 度および湿度がフライアッシュを用いたコンクリートの 強度に及ぼす影響, 土木学会論文報告集第 71 別冊, pp. $1 \sim 10,1960$.

13）小玉克巳・北村政幸 : 高炉スラグ微粉末を用いたコンク リートの諸性質, セメント技術大会第 32 回講演要旨, pp. $172 \sim 173,1978$.

(1978.2.15 - 受付) 